\title{
Ion Channel Targeting with Antibodies and Antibody Fragments for Cancer Diagnosis
}

\author{
Claudia Duranti and Annarosa Arcangeli * \\ Department of Experimental and Clinical Medicine, Section of Internal Medicine, University of Florence, \\ 50134 Firenze, Italy; claudia.duranti@unifi.it \\ * Correspondence: annarosa.arcangeli@unifi.it; Tel.: +39-055-2751283
}

Received: 21 March 2019; Accepted: 20 May 2019; Published: 24 May 2019

\begin{abstract}
The antibody era has greatly impacted cancer management in recent decades. Indeed, antibodies are currently applied for both cancer diagnosis and therapy. For example, monoclonal antibodies are the main constituents of several in vitro diagnostics, which are applied at many levels of cancer diagnosis. Moreover, the great improvement provided by in vivo imaging, especially for early-stage cancer diagnosis, has traced the path for the development of a complete new class of antibodies, i.e., engineered antibody fragments. The latter embody the optimal characteristics (e.g., low renal retention, rapid clearance, and small size) which make them ideal for in vivo applications. Furthermore, the present review focuses on reviewing the main applications of antibodies and antibody fragments for solid cancer diagnosis, both in vitro and in vivo. Furthermore, we review the scientific evidence showing that ion channels represent an almost unexplored class of ideal targets for both in vitro and in vivo diagnostic purposes. In particular, we review the applications, in solid cancers, of monoclonal antibodies and engineered antibody fragments targeting the voltage-dependent ion channel Kv 11.1, also known as hERG1.
\end{abstract}

Keywords: antibodies; cancer diagnostics; in vivo imaging; engineered antibody fragments; hERG1

\section{Introduction}

Antibodies have become common and essential research instruments over the last fifty years, providing highly specific and versatile tools for a wide array of experimental applications in many fields. Furthermore, monoclonal antibodies (mAbs) and, more recently, recombinant antibodies have gained clinical applications for diagnosis and therapy of different diseases, including cancer [1,2]. The translation of antibodies from basic research into the clinic has therefore significantly changed the prognosis for different classes of human cancers. The great success of the clinical application of antibodies mainly relies on the high versatility of these biological molecules. Indeed, antibodies combine the specificity of antigen targeting with, e.g., the possibility to be easily conjugated with various molecular or chemical agents, thus improving their pharmacological efficacy. Targeted therapeutic strategies have recently raised the possibility of tailoring cancer treatment to an individual patient after assessing the peculiar molecular characteristics of the tumor under treatment. Such refined diagnostic assessments can be achieved using antibody molecules. The fusion between diagnostic imaging techniques and therapeutic intervention is important to address cancer heterogeneity [3]. The term "theranostics" was hence coined to describe a molecular tool having both diagnostic and therapeutic applications [4]. Moreover, several platforms linking a diagnostic tool, often represented by an antibody, with a defined therapeutic compound have been developed and marketed. Such "companion diagnostics" are embodying an indispensable part of personalized cancer medicine [5].

The present review focuses on reviewing the main applications of $\mathrm{mAbs}$ for cancer diagnosis in vitro. Moreover, we address how the technology of engineering antibody molecules, and in particular the possibility of developing antibody fragments, is greatly impacting on in vivo molecular imaging, 
for diagnostic applications in solid cancers. We also provide strong evidence that ion channels are relevant molecular devices in cancer establishment and progression, and that can be exploited for either in vitro or in vivo cancer diagnosis. In particular, the diagnostic and prognostic applications, in solid cancers, of $\mathrm{mAbs}$ and antibody fragments targeting the voltage-dependent ion channel $\mathrm{K}_{\mathrm{v}} 11.1$, also known as hERG1, are thoroughly discussed.

\section{Antibody-Based Cancer Diagnostics}

Solid cancer diagnosis is currently based on imaging techniques (e.g., Computer-Assisted Tomography, Magnetic Resonance Imaging, etc.), laboratory assays (e.g., tests for circulating tumor markers such as the carcinoembryonic antigen) and the pathological evaluation of either biopsies or surgical specimens. The latter can take advantage of either biomolecular techniques or antibody-based immunohistochemistry (IHC) to provide further insights for patients' prognostic stratification and therapeutic choice. The number and type of techniques available to allow physicians to detect and diagnose cancer had significant changes in the last years. In fact, more accurate and reproducible imaging techniques have been developed and applied to the clinical setting. Moreover, novel cancer biomarkers have been identified to improve diagnosis and prognosis. In this scenario, antibodies represent key devices for both in vitro and in vivo diagnosis, since they can specifically recognize specific cancer biomarkers in tissues and body fluids. In particular, while mAbs represent good molecular tools to detect cancer biomarkers in vitro, in tissue specimens, their use in vivo is hindered by several concerns (see Section 3.2) and are progressively being substituted by antibody fragments [6].

Hereafter, the main antibody-based in vitro and in vivo techniques for cancer diagnosis are reported.

\subsection{In Vitro Cancer Diagnostics}

Solid cancer diagnosis in vitro is now routinely improved by the detection of clinically validated biomarkers through IHC on paraffin-embedded tissue slides. After antibody binding to the specific antigen, the target region can be visualized by an enzyme-linked (e.g., horseradish peroxidase) or a fluorescent dye, a radioactive tracer or a colloidal gold reagent. The positivity of the tumor for a given marker is hence evaluated, applying predetermined cutoffs. New IHC techniques have improved both the optical resolution and the sensitivity of detection, mainly through the use of amplification procedures, despite the risks of false-positive and false-negative staining [6]. Some "in vitro diagnostics" (IVD) based on antibodies (and the related IHC technique) have been clinically validated and are currently applied in the clinical practice (see Table 1). mAbs can also be utilized as "companion diagnostics", i.e., diagnostics that can be associated with the use of a particular treatment, either a small molecule or a therapeutic antibody. The path to companion diagnostics started in 1998 with the approval of the therapeutic humanized mAb Trastuzumab, which was paralleled by the simultaneous approval of a diagnostic test, the HercepTest. Some of the approved companion diagnostics are reported in Table 1.

An emerging application of antibodies for cancer diagnostic and prognostic purposes relies on the use of "omics" data [7]. However, both IHC and omics strategies display some disadvantages, since they can hardly address tumor heterogeneity. Furthermore, tumor biopsies are not always able to reveal the overall antibody binding or the overall expression of the biomarker. Both hindrances have been recently addressed through the so called "liquid biopsy", aimed at the detection of either circulating, cell-free, DNA or of circulating tumor cells (CTCs). CTCs detection can help to monitor a patient's condition, including the tracking of the genomic evolution of the tumor. CTC studies are accomplished through microfluidics platforms, and a new approach includes the use of EpCAM expression levels for the capture of CTCs. Besides anti-EpCAM antibodies, other antibodies targeting specific tumor biomarkers are now under development to improve microfluidic-based CTC analyses [8]. 
Table 1. Antibody-based in vitro diagnostics (IVDs) which are already approved by the FDA (Federal Drug Administration) and/or EMA (European Medicine Agency) and used for cancer diagnosis. CTA, Cancer-testis antigen; CEA, carcinoembryonic antigen; PSMA, prostate-specific membrane antigen; TAG-72, tumor-associated glycoprotein 72; PDL-1, programmed death-ligand 1; HER 2, human epidermal growth factor receptor 2; EGFR, epidermal growth factor receptor; ALK, anaplastic lymphoma kinase.

\begin{tabular}{|c|c|c|c|c|c|c|}
\hline IVD Commercial Name & Manufacturer & Antigen & Antibody Format & Tumor Type & Diagnostic Significance & Possibility of Companion Diagnostic \\
\hline Humaspect ${ }^{\circledR}$ & Organon Teknica & СТА & Humanized mAb & $\begin{array}{c}\text { Colorectal cancer/tumor } \\
\text { detection }\end{array}$ & & NA \\
\hline CEA-scan ${ }^{\circledR}$ & Immunomedics & CEA & Murine Fab fragment & $\begin{array}{l}\text { Colorectal cancer/tumor } \\
\text { detection }\end{array}$ & $\begin{array}{l}\text { Tumor marker, Prognostic } \\
\text { marker }\end{array}$ & NA \\
\hline $\operatorname{ProstaScint}^{\circledR}$ & Cytogen & PSMA & Murine $\mathrm{mAb}$ & $\begin{array}{l}\text { Prostate adenocarcinoma/tumor } \\
\text { detection }\end{array}$ & Prognostic marker & NA \\
\hline Verluma $^{\circledR}$ (Diagnostic) & Boehringer Ingelheim, NeoRx & CD-20 & Murine Fab fragment & $\begin{array}{l}\text { Small-cell lung cancer/tumor } \\
\text { detection }\end{array}$ & & NA \\
\hline OncoScint ${ }^{\circledR}$ & Cytogen & TAG-72 & Murine $\mathrm{mAb}$ & $\begin{array}{l}\text { Colorectal and ovarian } \\
\text { cancer/tumor detection }\end{array}$ & & NA \\
\hline PD-L1 IHC 22C3 pharmDx & Dako North America Inc. & PDL-1 & Murine $\mathrm{mAb}$ & $\begin{array}{l}\text { Non-small-cell lung } \\
\text { cancer/tumor detection }\end{array}$ & & $\begin{array}{c}\text { Yes } \\
\text { Keytruda (pembrolizuma)_BLA } 125514\end{array}$ \\
\hline $\begin{array}{l}\text { VENTANA PD-L1(SP142) } \\
\text { Assay }\end{array}$ & Ventana Medical Systems, Inc. & PDL-1 & Rabbit mAb & $\begin{array}{l}\text { Non-small-cell lung cancer and } \\
\text { urothelial cancer/tumor detection }\end{array}$ & & $\begin{array}{l}\text { Yes } \\
\text { Tecentriq (atezolizumab)—NDA 761034/S012 }\end{array}$ \\
\hline Dako EGFR pharmDx Kit & Dako North America, Inc. & EGFR & $\begin{array}{l}\text { Murine } m A b \text {, (clone } \\
\quad 2-18 C 9 \text { ) }\end{array}$ & $\begin{array}{l}\text { Colorectal cancer/tumor } \\
\text { detection }\end{array}$ & & $\begin{array}{c}\text { Yes } \\
\text { Erbitux (cetuximab)-BLA } 125084 \\
\text { Vectibix (panitumuma)-BLA } 125147\end{array}$ \\
\hline $\begin{array}{l}\text { PATHWAY anti-Her2/neu } \\
\text { (4B5) }\end{array}$ & Ventana Medical Systems, Inc. & HER2 & Rabbit mAb & Breast cancer/tumor detection & & $\begin{array}{l}\text { Yes } \\
\text { Herceptin (trastuzumab)—BLA } 103792\end{array}$ \\
\hline $\begin{array}{l}\text { Bond Oracle HER2 IHC } \\
\text { System }\end{array}$ & Laica Biosystem & HER2 & $\begin{array}{c}\mathrm{mAb} \\
\text { (CB11 clone) }\end{array}$ & Breast cancer detection & $\begin{array}{l}\text { Tumor marker, Prognostic } \\
\text { marker }\end{array}$ & $\begin{array}{c}\text { Yes } \\
\text { Herceptin (trastuzumab)—BLA } 103792\end{array}$ \\
\hline HercepTest & Dako Denmark A/S & HER2 & Rabbit mAb & Breast cancer detection & $\begin{array}{l}\text { Tumor marker, Prognostic } \\
\text { marker }\end{array}$ & $\begin{array}{c}\text { Yes } \\
\text { Herceptin (trastuzumab)—BLA } 103792 \\
\text { Yes }\end{array}$ \\
\hline $\begin{array}{l}\text { VENTANA ALK (D5F3) CDx } \\
\text { Assay }\end{array}$ & Ventana Medical Systems, Inc. & ALK & Rabbit mAb & $\begin{array}{l}\text { Non-small-cell lung carcinoma } \\
\text { detection }\end{array}$ & $\begin{array}{l}\text { Tumor marker, Prognostic } \\
\text { marker }\end{array}$ & $\begin{array}{l}\text { Zykadia (ceritinib)-NDA } 205755 \\
\text { Xalkori (crizotinib)-NDA } 202570 \\
\text { Alecensa (alectinib)—NDA } 208434\end{array}$ \\
\hline
\end{tabular}




\subsection{In Vivo Cancer Diagnostics: Molecular Imaging}

The accuracy that allows antibodies to precisely identifying their targets has stimulated their application also for in vivo imaging, thus improving the diagnostic imaging approaches currently used. For example, the 18F-Fluoridexyglucose-Positron Emission Tomography (FDG-PET) imaging represents an invaluable diagnostic and prognostic tool to detect high levels of glycolytic activity, a sign of malignant transformation. However, FDG-PET is not free of false negatives (e.g., tumors with more indolent growth or dependent on different metabolic pathways) or false positives, as in the case of infection or inflammation [9]. Notably, the majority of imaging probes actually in use to detect cancer can also detect inflammation, thus leading to significant numbers of potential false positives. Hence, using antibodies for in vivo imaging may lead to a versatile approach which allows more accurate diagnosis, staging and hence disease management. Some practical examples of mAbs recognizing cancer specific biomarkers that are approved by the FDA and/or EMA and are currently used in the clinical setting are shown in Table 2A. Among these, ProstaScint is a mAb used in prostate cancer patients as a diagnostic imaging agent to detect nodal metastases "pre-prostatectomy", or recurrence in post prostatectomy patients with a rising prostate-specific antigen (PSA). The therapeutic mAbs, cetuximab and trastuzumab, are also used as in vivo tracers. In particular, the dual-labeled ( ${ }^{111} \mathrm{In}$-DTPA)n-trastuzumab-(IRDye800)m is capable of tracking HER2 overexpression in breast cancer patients [10]. cetuximab has been repurposed for fluorescent imaging and is in phase I and phase II clinical trials for malignant glioma and pancreatic cancer imaging and fluorescence-guided surgery with IRDye-800CW [11].

Table 2. Antibodies for in vivo use in tumor imaging diagnostics approved by the FDA and/or EMA and present on the market. CEA, carcinoembryonic antigen; Tc, technetium; In, indium.

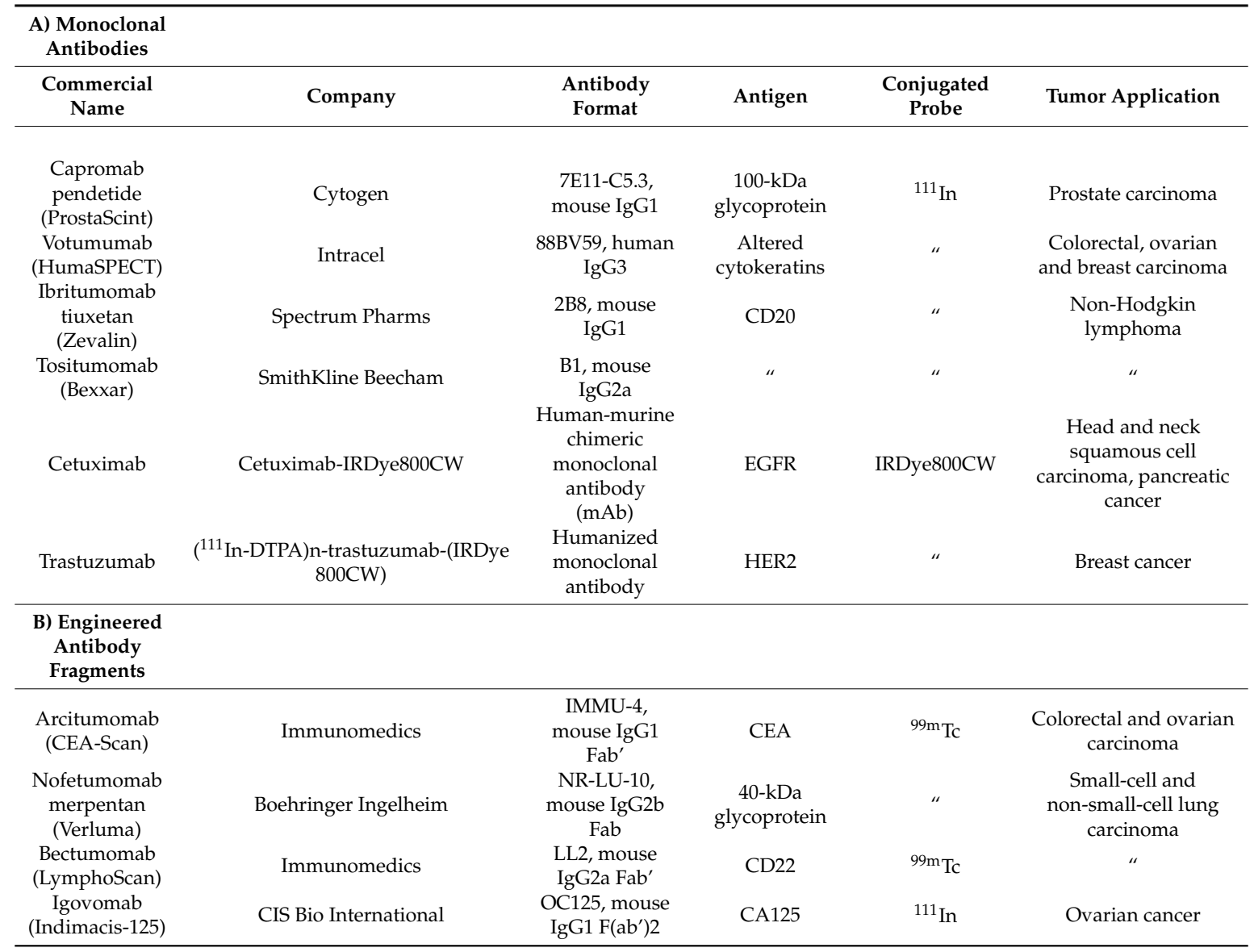

Although antibodies have definitely improved cancer diagnostics through their application in IVD kits, the use of mAbs as molecular imaging tools for in vivo diagnostics still needs further improvements. 
In other words, antibodies need to be designed differently for their use as diagnostics in vitro and for their application as in vivo imaging agents. When injected in vivo, in fact, whole antibodies display long serum half-lives (1-3 weeks), which are favorable if they are envisaged to be applied as therapeutics, thanks to the enhancement of the exposure of target tissues to the antibody. Moreover, the effector domain (crystallizable fragment, Fc) often exerts biological activities which are essential for the therapeutic functions of the whole antibody molecule [12]. However, such characteristics are drawbacks for the use of such molecules as imaging agents, as several days are required to obtain a good signal-to-noise ratio, and a biological activity is undesirable for an imaging agent.

Many of the disadvantages of whole antibody molecules have been overcome thanks to antibody engineering, producing smaller and highly versatile molecules [13], which maintain the specificity of mAbs but allow higher tumor penetration and shorter clearance times, both optimal characteristics for diagnostic purposes.

\section{Antibody Fragments for Cancer Diagnostics}

Generally, the preservation of the variable fragment $(\mathrm{Fv})$ domain in engineered antibody fragments preserves the antigen binding. Conversely, the absence of the Fc region abolishes the immune interactions mediated by the complement and by other effectors. The elimination of the Fc region also blocks recycling through the path of the neonatal $F_{C}$ receptor ( $\left.F_{C} R n\right)$, facilitating the contrast and thus the visualization of targeted tissues through rapid clearance from the blood [13]. Smaller fragments allow the use of radionuclides that decay rapidly (for example through labeling with $18 \mathrm{~F}$ ), thus resulting in reduced radiation exposure. Furthermore, the use of antibodies with a reduced molecular weight (below $\sim 60 \mathrm{kDa}$ ) speeds up the elimination through the renal clearance [14]. The main structural characteristics, molecular weight and renal clearance of different engineered antibody fragments are shown in Figure 1 and described in the following paragraph.

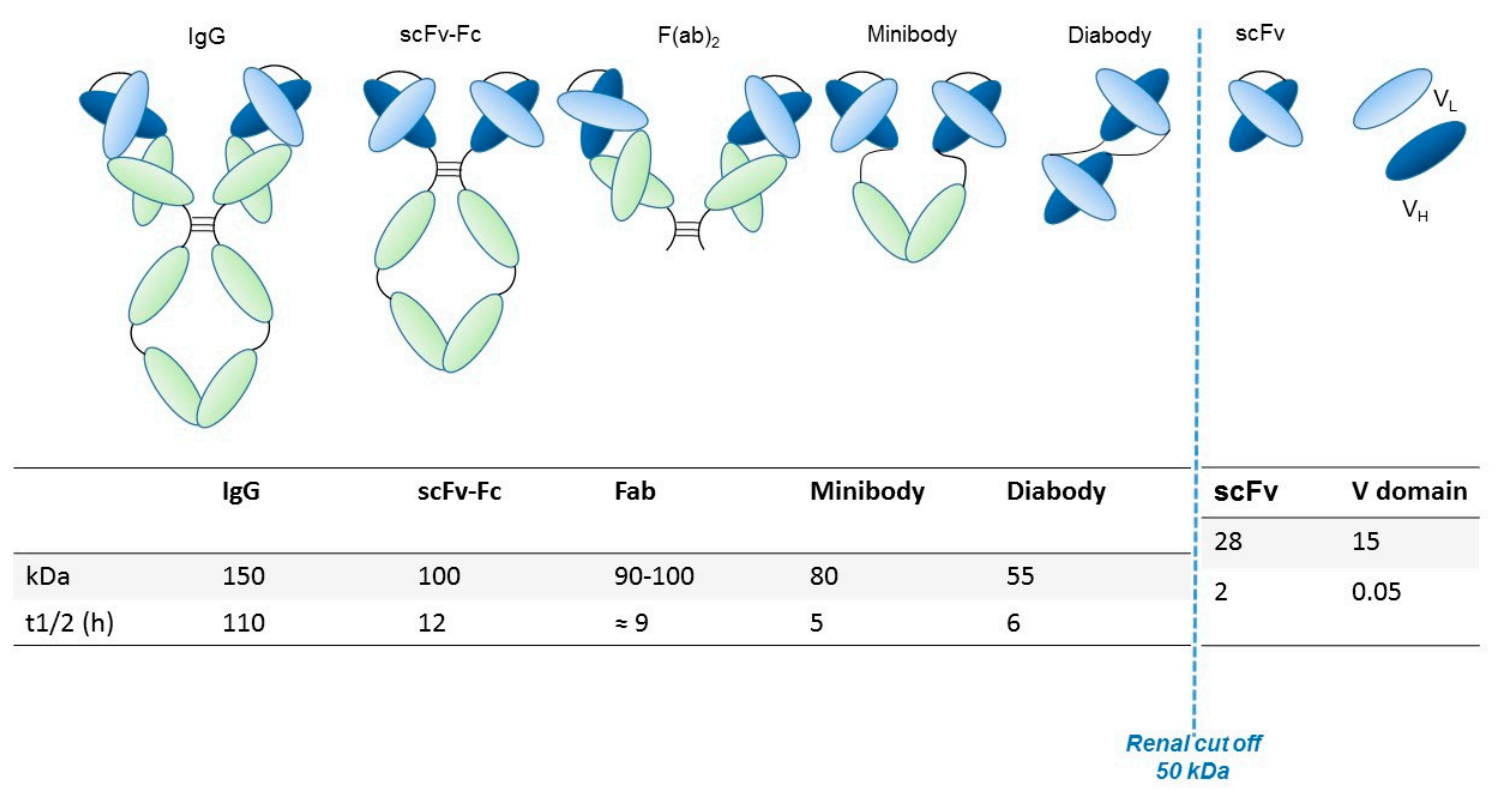

Figure 1. Engineered antibody formats. Different antibody formats are reported in the figure, showing their different size compared to intact IgG. Ig, Immunoglobulin; scFv, single-chain variable fragment; $\mathrm{V}$ domain, variable domain. In the figure, the size (KDa) of each different antibody format and their half-lives ( $\mathrm{t}_{1 / 2}$, i.e., time needed to eliminate half of the molecule from circulation) are also reported.

\subsection{Antibody Fragments: Characteristics and Development}

A comparison of the pharmacokinetics and target specificities between intact and fragmented antibodies has been performed, and the results show that recombinant antibodies retain the antigen 
specificity of the intact Igs from which they derive advantageous characteristics regarding tumor penetrance and retention. Furthermore, antibody fragments have several formats which are reported in Figure 1: scFv-Fc $(\approx 100 \mathrm{KDa})$, minibodies $(\mathrm{Mb}$; scFv-CH3 dimers, $\approx 80 \mathrm{kDa}), \mathrm{F}\left(\mathrm{ab}^{\prime}\right) 2$ and Fab $(\approx 50 \mathrm{KDa})$, bispecific antibodies $(\approx 55-60 \mathrm{KDa})$ and $\mathrm{scFv}(\approx 25 \mathrm{KDa})$ [12]. The $\mathrm{F}(\mathrm{ab})$ fragment is an antibody structure that still binds to antigens but is monovalent and lacks the Fc portion. An antibody digested by the enzyme papain yields two F(ab) fragments of about $50 \mathrm{kDa}$ each and an Fc fragment [15].

Another class of antibody fragments is based on single-domain antibodies.

Among sdAbs, the so called nanobodies merit attention. Nanobodies ( $15 \mathrm{kDa})$ are fragments of heavy single-variable heavy chains $\left(\mathrm{VH}_{\mathrm{H}} \mathrm{s}\right)$, originated from antibodies found in the camelids. The small size of these antibodies allows them to bind to epitopes to which intact molecules cannot access [16] and makes them appropriate for applications where an extremely short time of clearance is desired. The latter is also determined by the size, the charge and by the presence/absence of conjugated parts. Fragments with weights lower than the renal threshold ( $60 \mathrm{kDa})$ are eliminated through the kidneys, while larger molecules are instead cleared through the liver. Nanobodies can be used in diagnostics both at the initial stages for the detection of the tumor itself and then to evaluate the expression of a target for therapeutic intervention or for monitoring of the disease. This class of molecules can be coupled with various nanocarriers (e.g., iron oxide nanoparticles, silica nanoparticles, gold nanostructures, and carbon nanomaterials), which could be suitable for anticancer drug delivery [17].

From the diagnostic point of view, two important classes of antibody fragments are the scFvs, single-chain variable fragments, and the bispecific antibodies. scFvs have a molecular weight around $25 \mathrm{kDa}$ and are composed of $\mathrm{V}_{\mathrm{H}}$ and $\mathrm{V}_{\mathrm{L}}$ chains, joined via a flexible peptide linker. The first $\mathrm{scFv}$ molecules were developed in 1988 and represent the smallest functional $\mathrm{V}_{\mathrm{H}}-\mathrm{V}_{\mathrm{L}}$ domains of an antibody necessary for the high-affinity binding of an antigen. Peptide linkers are fundamental for the assembly of functional scFv antibodies, as they join the VH and VL chains and usually vary from 10 to 25 amino acids in length and typically include hydrophilic amino acids. The most common linker is the decapenta-peptide (Gly4Ser)3. The variable regions can be connected in either the VH-linker-VL (most common) or VL-linker-VH orientation. In any case, such orientations can affect expression efficiency, stability and antigen binding activity [18].

Another class of antibodies which has gained great attention is that of bispecific antibodies, among which single-domain diabody $(\mathrm{scDb})$ is the most versatile format. The first work on bispecific antibody generation was published in 1961 and described the production of chimeric antibodies containing two different antigen-binding sites simultaneously. Such molecules are capable of binding two different antigens at the same time, thus allowing the recognition of two different targets which might be crucial in the diagnostic setting. scDbs conjugate the bispecificity with the characteristics (low molecular weight, high tissue penetration, and good clearance times) of antibody fragments [19].

\subsection{Applications of Antibody Fragments for in Vivo Imaging}

Recent examples of antibody fragments used as in vivo diagnostics combined encompass several of the aforementioned formats even though this field offers great space for improvement as few of such molecules are actually used for in vivo imaging diagnostic applications. Among those few are many Fab fragments for HER2 (human epidermal growth factor receptor 2) targeting and the use of ${ }^{124}$ I-PSCA (Prostate Stem Cell Antigen)-specific minibody in order to assess the response to prostate cancer treatment using enzalutamide [9]. Moreover, F(ab')2 and Fab fragments radiolabeled with ${ }^{111}$ In (Indio111) and minibodies and diabodies labeled with 89Zr (Zirconium 89) have been used for imaging with SPECT (Single Photon Emission Computed Tomography) or PET (Positron Emission Tomography) in small animals targeting the prostate-specific membrane antigen (PSMA). The great interest in fragments of antibodies is demonstrated by several papers using nanobodies [20,21] and affibodies [22]. So far, preclinical studies have been performed to give insights into the biochemical and biophysical features of several antibody fragments as imaging agents [23,24]. Ogasawara and colleagues demonstrated that antibodies specific for phosphatidylserine can be a valuable tool to assess 
cell death in response to treatment [25]. Direct imaging with antibodies could also offer a suitable technique to determine the development of resistance to therapy. Li and colleagues [9] focused on MET receptor, using various antibody fragments derived from an anti-MET antibody to obtain images of non-small-cell lung cancer xenografts from cell lines resistant to targeted anti-EGFR therapy due to the overexpression of MET.

Finally, bispecific radioimmunoconjugates (bsRICs) capable of binding to HER2 and EGFR were developed for both therapy and diagnostic applications and tested in preclinical models. The aim of these studies was to better decipher the mechanisms underlying trastuzumab resistance related to the overexpression of EGFR in patients with HER2-positive carcinomas. These bsRICs are composed of the trastuzumab Fab (ligand for HER2) linked to EGF (ligand for EGFR) via a long spacer (polyethylene glycol). Such antibodies show good specificity and low uptake in normal organs except for the kidneys [26]. We report, in Table 2, the main monoclonal and engineered antibody fragments which are used in vivo and have already been approved by the FDA and/or EMA.

\section{Ion Channels in Cancer}

Ion channels are membrane proteins which, besides controlling cell excitability and ionic and fluid homeostasis, are emerging to be particularly relevant in cancer [27]. In particular, being mainly present on the plasma membrane of cancer cells, ion channels can mediate the cross-talk between tumor cells and the tumor microenvironment to drive different features of neoplastic progression (e.g., cell proliferation and survival, cell invasiveness, and pro-angiogenic programs) [28]. What is more, ion channels represent one of the rare druggable molecular classes and are increasingly recognized as novel and valuable molecular targets for antineoplastic therapy [29]. Some ion channel modulators, previously used in not oncological settings, are currently in clinical trials for cancer treatment (https://clinicaltrials.gov/).

Ion channels are involved in tumor progression through different mechanisms. For example, $\mathrm{K}^{+}$channels allow uncontrolled tumor cell proliferation by setting the membrane potential (Vm) to rather depolarized values. The $\mathrm{Ca}^{2+}$-dependent $\mathrm{K}^{+}\left(\mathrm{K}_{\mathrm{Ca}}\right)$ channels can couple $\mathrm{V}_{\mathrm{m}}$ to variations of the intracellular $\mathrm{Ca}^{2+}$ concentration $\left(\left[\mathrm{Ca}^{2+}\right]_{\mathrm{i}}\right)$. The latter is a finely tuned process that involves both plasma membrane (e.g., ORAI1 and TRPC1 channels) and intracellular (e.g., STIM1) proteins. In several types of cancer cells, $\left[\mathrm{Ca}^{2+}\right]_{\mathrm{i}}$ regulates critical cellular processes such as gene expression and motility. Another channel type likely relevant to cancer is the volume-regulated anion channel VRAC, formed by a multimeric assembly of LRRC8A-LRRC8E proteins. The regulatory effects of VRAC on cellular volume (in particular in the process called apoptotic volume decrease (AVD)) play a crucial role in cancer progression and metastasis, as well as in drug resistance.

Another anion channel frequently upregulated in cancer is the $\mathrm{Ca}^{2+}$-activated $\mathrm{Cl}^{-}$channel TMEM16A, also called ANO1. Voltage-gated sodium $\left(\mathrm{Na}_{\mathrm{V}}\right)$ channels are often expressed de novo in carcinomas. Besides contributing to tumor "electrical excitability", they can regulate intracellular $\mathrm{Na}^{+}$concentrations $[\mathrm{Na}]_{\mathrm{i}}$ and in turn activate $\mathrm{Na}^{+}$-driven exchangers. In any case, $\mathrm{Na}_{\mathrm{v}}$ are mainly involved in the triggering of cell invasiveness and metastatic spread. The Transient Receptor Potential (TRP) channels are also dysregulated in cancer, where they can also operate in conjunction with growth factor receptors: TRPC1 binds to the Fibroblast Growth Factor Receptor (FGFR1) and drives cell proliferation by a modulation of bFGF-triggered $\mathrm{Ca}^{2+}$ signals; the TRP Ankyrin 1 (TRPA1) channel binds to FGFR2 in lung adenocarcinoma cells, and activates the metastatic process thanks to this strict binding. Some cancer-related ion channels operate in a non-canonical way: $\mathrm{K}_{\mathrm{v}} 11.1$ (hERG1), for example, is strictly associated with the $\beta 1$ subunit of integrin adhesion receptors in tumors, and stimulates peculiar intracellular signaling pathways that regulate the metastatic process [30]. Besides the plasma membrane, ion channels are present in intracellular organelles of tumor cells, such as mitochondria, where they play a central role in the regulation of either metabolic state or apoptosis. The expression and role of ion channels in cancers has been extensively reviewed by us and other authors. Hence we refer to extensive reviews and related references for further details on this topic [27-31]. The main ion channel types expressed in solid cancers are depicted in Figure 2 and listed 
in Table 3. A concise picture of the functional aspects of ion channels and a focus on the structural features of voltage-gated ion channels are shown in Box 1 and Figure 3.

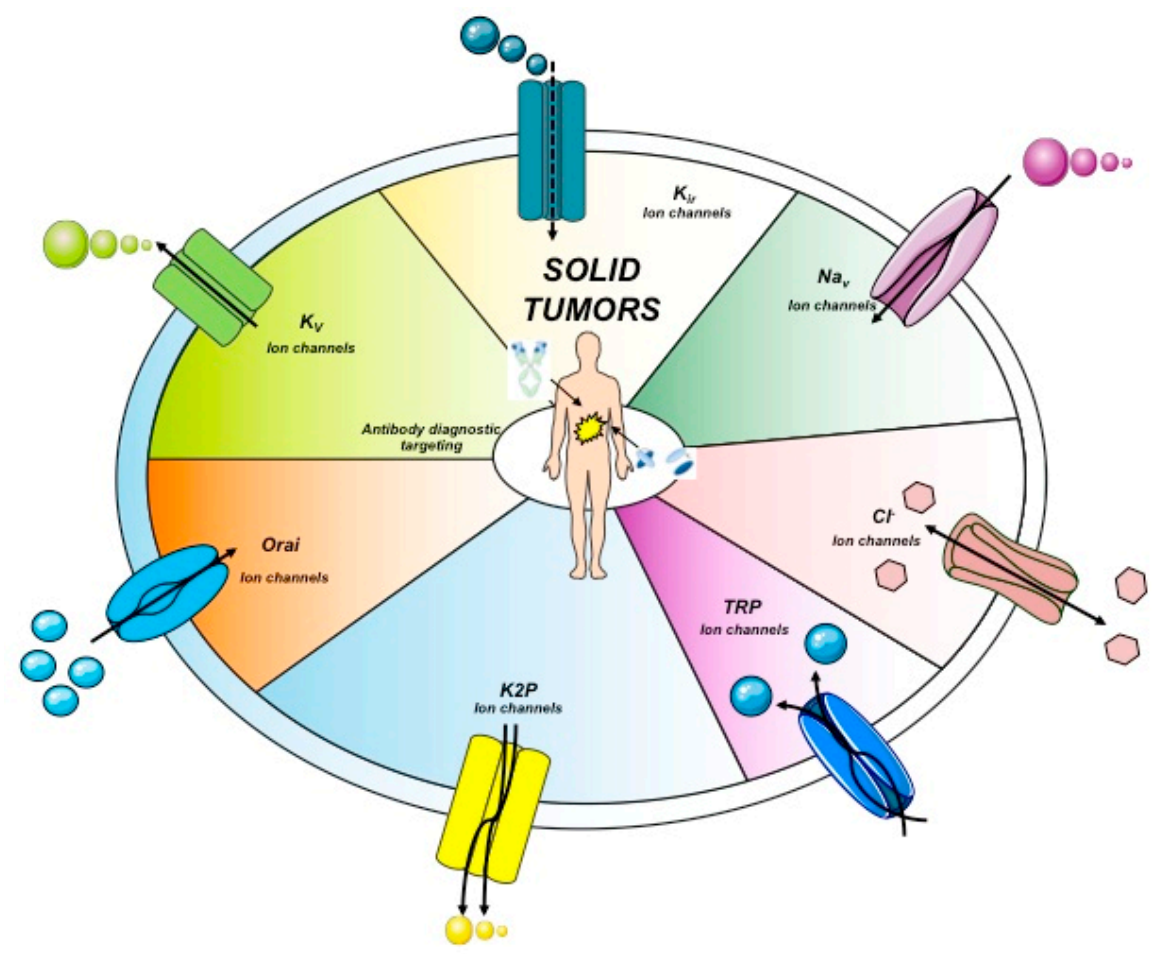

Figure 2. Ion channels topology expressed in solid cancers. The main ion channels and their structures are reported. These represent the main proteins expressed in solid cancers. $K_{i r}$, inward-rectifier potassium channel.

Table 3. Main ion channels expressed in solid cancers, with their role in tumor biology. Ion channels are indicated using the HGNC (HUGO Gene Nomenclature Committee) classification. Cancers are indicated using the acronyms as follows: $\mathrm{BC}$, breast cancer; $\mathrm{PDAC}$, pancreatic cancer; $\mathrm{CRC}$, colorectal cancer; LC, lung cancer; HC, head cancer; PC, prostate cancer; EC, esophageal cancer; GC, gastric cancer. Firstly, voltage-gated potassium channels are reported, followed by calcium-activated potassium channels. For each channel, it has been indicated whether it is an early biomarker (eb), which allows early detection of the cancer in a noninvasive way and thus the secondary prevention of the cancer; a prognostic biomarker $(\mathrm{pb})$, which is a clinical or biological characteristic that provides information on the likely course of the disease and gives information about the outcome of the patient; or a tumor marker (tm), which are proteins that can be elevated by the presence of one or more types of cancer.

\begin{tabular}{|c|c|c|c|c|}
\hline Name & Tumor Type & Role in Tumor Biology & $\begin{array}{c}\text { Exploitation for } \\
\text { Diagnostic Purposes }\end{array}$ & Reference \\
\hline \multicolumn{5}{|l|}{ Potassium } \\
\hline KCNH1 & $\begin{array}{l}\text { BC, EC, PDAC, } \\
\text { CRC }\end{array}$ & $\begin{array}{l}\text { Modulation of cell cycle and } \\
\text { proliferation }\end{array}$ & $\mathrm{tm}, \mathrm{pm}$ & [32] \\
\hline KCNH2 & & Reviwed in detail in Table 4 & & \\
\hline KCNA3 & PC, PDAC, CRC & $\begin{array}{l}\text { Tumor progression, Metastatic } \\
\text { spreading }\end{array}$ & $\mathrm{tm}, \mathrm{pm}$ & [33-35] \\
\hline KCNA5 & “ & P " & $\mathrm{tm}$ & [36] \\
\hline KCNQ1 & $\mathrm{LC}$ & Hypoxia Resistance & $\mathrm{tm}$ & [37] \\
\hline KCNQ5 & CRC & Cell proliferation & $\mathrm{tm}$ & [38] \\
\hline KCNMA1 & $\mathrm{BC}, \mathrm{PC}$ & $\begin{array}{l}\text { Modulation of cell cycle and } \\
\text { proliferation, Cell proliferation }\end{array}$ & $\mathrm{tm}, \mathrm{pm}$ & {$[39,40]$} \\
\hline $\mathrm{KCNN} 4$ & $\mathrm{BC}, \mathrm{PDAC}$ & $\begin{array}{l}\text { Modulation of cell cycle and Cell } \\
\text { proliferation }\end{array}$ & $\mathrm{tm}, \mathrm{pm}$ & {$[41,42]$} \\
\hline $\mathrm{KCNC} 4$ & CRC & 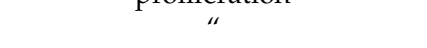 & $\mathrm{tm}$ & [43] \\
\hline
\end{tabular}


Table 3. Cont

\begin{tabular}{|c|c|c|c|c|}
\hline Name & Tumor Type & Role in Tumor Biology & $\begin{array}{c}\text { Exploitation for } \\
\text { Diagnostic Purposes }\end{array}$ & Reference \\
\hline KCNJ3 & $\mathrm{BC}, \mathrm{PDAC}$ & $\begin{array}{c}\text { Modulation of cell cycle and Cell } \\
\text { proliferation }\end{array}$ & $\mathrm{tm}, \mathrm{pm}$ & {$[43,44]$} \\
\hline KCNK5 & $\mathrm{BC}$ & $\begin{array}{l}\text { Modulation of cell cycle and } \\
\text { proliferation }\end{array}$ & $\mathrm{tm}, \mathrm{pm}$ & [45] \\
\hline $\begin{array}{l}\text { KCNK9 } \\
\text { Sodium }\end{array}$ & $\mathrm{BC}, \mathrm{CRC}$ & “ & pm & {$[46,47]$} \\
\hline SCN5A & $\mathrm{BC}, \mathrm{CRC}$ & $\begin{array}{l}\text { Cell proliferation and } \\
\text { invasiveness }\end{array}$ & $\mathrm{tm}$ & {$[48,49]$} \\
\hline SCN9A & PC, LC & $\begin{array}{l}\text { Migration and metastatic } \\
\text { spreading }\end{array}$ & $\mathrm{tm}, \mathrm{pm}$ & {$[50,51]$} \\
\hline \multicolumn{5}{|l|}{ Calcium } \\
\hline CACNA2D & $\mathrm{BC}$ & Cell proliferation & NA & [52] \\
\hline CACNA1H & PC & 1 & $\mathrm{tm}$ & [53] \\
\hline CACNA & $\mathrm{EC}, \mathrm{CRC}$ & Cell proliferation, Cell invasion & $\mathrm{tm}$ & {$[54,55]$} \\
\hline CACNA2D3 & GC, HC & Tumor suppression & $\mathrm{tm}$ & {$[56,57]$} \\
\hline ATP2C1 & $\mathrm{BC}$ & Cell proliferation & $\mathrm{tm}, \mathrm{pm}$ & {$[58]$} \\
\hline ATP2B2 & “ & " & $\mathrm{tm}$ & [59] \\
\hline ORAI1 & $\mathrm{BC}, \mathrm{PC}$ & Cell invasion, Cell survival & $\mathrm{tm}$ & " \\
\hline ORAI3 & $\mathrm{BC}, \mathrm{LC}$ & $\begin{array}{l}\text { Cell proliferation and } \\
\text { invasiveness }\end{array}$ & $\mathrm{tm}$ & [60] \\
\hline \multicolumn{5}{|l|}{ Chloride } \\
\hline ANO1 & $B C, P D A C$ & $\begin{array}{l}\text { Cell proliferation and } \\
\text { invasiveness }\end{array}$ & $\mathrm{tm}$ & {$[61,62]$} \\
\hline CLCA1 & CRC & $\begin{array}{l}\text { Cell proliferation and } \\
\text { invasiveness }\end{array}$ & $\mathrm{tm}$ & [63] \\
\hline \multirow[t]{2}{*}{ CLCA2 } & $\mathrm{BC}$ & Tumor suppression & $\mathrm{tm}$ & [64] \\
\hline & CRC & Cell differentiation & $\mathrm{tm}$ & [65] \\
\hline CLCA4 & “ & Tumor suppression & $\mathrm{tm}$ & [65] \\
\hline CLIC1 & CRC, GC & $\begin{array}{l}\text { Migration and metastatic } \\
\text { spreading, Cell proliferation, } \\
\text { apoptosis, invasiveness }\end{array}$ & $\mathrm{tm}$ & [66] \\
\hline $\begin{array}{l}\text { CLIC3 } \\
\text { TRP }\end{array}$ & PDAC & Cell survival & $\mathrm{tm}$ & [67] \\
\hline TRPM8 & $\mathrm{BC}, \mathrm{PC}, \mathrm{PDAC}$ & “ & $\mathrm{tm}, \mathrm{pm}$ & [68-70] \\
\hline TRPM7 & $\mathrm{BC}, \mathrm{PDAC}$ & $\begin{array}{l}\text { Cell proliferation and } \\
\text { invasiveness }\end{array}$ & $\mathrm{tm}$ & {$[71,72]$} \\
\hline TRPA1 & LC & Cell survival & $\mathrm{tm}, \mathrm{pm}$ & [73] \\
\hline TRPC1 & $\mathrm{BC}, \mathrm{PC}, \mathrm{LC}$ & $\begin{array}{l}\text { Cell proliferation, Migration and } \\
\text { metastatic spreading AND Cell } \\
\text { survival }\end{array}$ & $\mathrm{tm}$ & {$[74,75]$} \\
\hline TRPC3 & $\mathrm{BC}, \mathrm{LC}$ & Cell proliferation, Cell survival & $\mathrm{tm}$ & [76] \\
\hline TRPC4 & LC & Cell proliferation, Cell survival & $\mathrm{tm}$ & [77] \\
\hline TRPC6 & LC, EC & “ & $\mathrm{tm}, \mathrm{eb}, \mathrm{pm}$ & {$[78,79]$} \\
\hline TRPV1 & PDAC & Cell proliferation & $\mathrm{tm}, \mathrm{pm}$ & {$[80]$} \\
\hline TRPV4 & $\mathrm{BC}$ & $\begin{array}{l}\text { Migration and metastatic } \\
\text { spreading }\end{array}$ & $\operatorname{tm}$ & [81] \\
\hline TRPV6 & PC & Reduction of cell growth & $\mathrm{tm}$ & [82] \\
\hline
\end{tabular}


Table 4. Different human solid tumors in which the Kv11.1 (hERG1) ion channel is expressed, enlightening pre-clinical and clinical aspects in which it is involved. The different types of cancers have been indicated using acronyms as follows: Head\&Neck, HNSCC; Oral squamous cell carcinoma, OSCC; Glioblastoma Multiforme, GBM; NB, neuroblastoma; BC, breast cancer; PDAC, pancreatic cancer; P. NET, pancreatic neuroendocrine tumor; CRC, colorectal cancer; LC, lung cancer; HC, head cancer; PC, prostate cancer; EC, esophageal cancer; GC, gastric cancer; BE, Barrett's Esophagus; EC, endometrial cancer; OC, ovarian cancer; ML, melanoma; OSR, osteosarcoma.

\begin{tabular}{|c|c|c|c|c|}
\hline \multirow[t]{2}{*}{ Tumor Type } & \multicolumn{3}{|c|}{ hERG1 Involvement in Cancer Biology Aspects } & \multirow[t]{2}{*}{ References } \\
\hline & Effect in vitro & $\begin{array}{l}\text { Signaling pathway } \\
\text { affected }\end{array}$ & $\begin{array}{l}\text { Consequences of hERG1 } \\
\text { blockade in vivo }\end{array}$ & \\
\hline $\begin{array}{l}\text { HNSCC } \\
\text { OSCC }\end{array}$ & $\begin{array}{l}\text { HNSCC: Migration OSCC: } \\
\text { Invasiveness }\end{array}$ & $\begin{array}{l}\text { Sphingosine 1-phosphate } \\
\text { (S1P) receptors }\end{array}$ & NA & {$[83,84]$} \\
\hline GBM & Proliferation, Ki67 & Vegf & NA & [85] \\
\hline NB & Cell cycle regulation & NA & $\begin{array}{l}\text { Reduction of mean tumor } \\
\text { weight in mice treated } \\
\text { with hERG1 and hERG1b } \\
\text { inhibitor ZC88 }\end{array}$ & [86] \\
\hline LC & $\begin{array}{l}\text { Proliferation (small-cell } \\
\text { lung cancer (SCLC)) }\end{array}$ & NA & NA & [87] \\
\hline PDAC & $\begin{array}{l}\text { Proliferation } \\
\text { Migration Invasiveness }\end{array}$ & EGF-R signaling pathway & $\begin{array}{l}\text { Block of local growth and } \\
\text { of metastatic spread }\end{array}$ & [88-90] \\
\hline CRC & $\begin{array}{c}\text { Invasiveness Angiogenesis } \\
\text { Metastasis }\end{array}$ & $\begin{array}{l}\text { Akt, NFkB, HIF- } 1 / 2 \alpha, \\
\text { VEGFHIF-1/2 } \alpha\end{array}$ & $\begin{array}{l}\text { Block of local growth and } \\
\text { of metastatic spread }\end{array}$ & [91-94] \\
\hline $\mathrm{BE}, \mathrm{EC}$ & NA & $\mathrm{NA}$ & NA & {$[95,96]$} \\
\hline GC & $\begin{array}{l}\text { Cell proliferation } \\
\text { Apoptosis } \\
\text { VEGF-A secretion }\end{array}$ & AKT, pAKT, HIF2 $\alpha$, VEGF & $\begin{array}{l}\text { Block of local growth } \\
\text { Combined activity of } \\
\text { hERG1 blockers and } \\
\text { anti-VEGF-A antibodies } \\
\text { (Bevacizumab) }\end{array}$ & [97-100] \\
\hline P. NET & NA & NA & NA & [101] \\
\hline $\mathrm{BC}$ & $\begin{array}{l}\text { Induction of cell } \\
\text { senescence } \\
\text { Activation of p21/waf } \\
\text { transcription } \\
\text { Metastasis }\end{array}$ & $\begin{array}{l}\text { Ras-dependent } \\
\text { DNA damage } \\
\text { Actin assembly }\end{array}$ & Block of metastatic spread & {$[102,103]$} \\
\hline EC & NA & NA & NA & [104] \\
\hline OC & Proliferation & NA & NA & [105-107] \\
\hline ML & $\begin{array}{l}\text { Proliferation } \\
\text { Migration }\end{array}$ & $\begin{array}{l}\text { MAP kinase/c-fos } \\
\text { pathway. }\end{array}$ & NA & {$[108,109]$} \\
\hline OSC & $\begin{array}{c}\text { Proliferation, Migration, } \\
\text { Apoptosis }\end{array}$ & PI3K/Akt/NFkB & NA & [110] \\
\hline
\end{tabular}

Voltage-gated $\mathrm{K}^{+}$channel

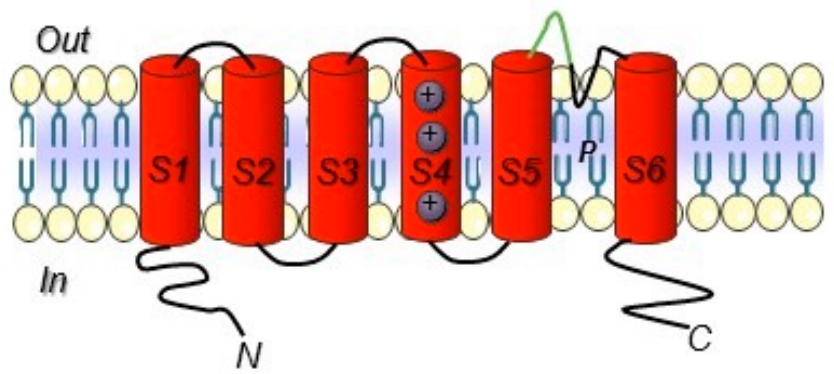

Figure 3. Voltage-gated $\mathrm{K}^{+}$ion channel topology. The six transmembrane segments S1-S6 are reported. The S5 and S6 domain are connected with a loop that control selectivity. In green, the loop portion towards which the hERG1-mAb was developed is highlighted (see the following paragraphs). Both the $\mathrm{N}$ - and $\mathrm{C}$ - terminus are intracellular. 
Box 1. Insights into ion channel main structure features.

\section{Focus on Ion channels}

Functional features:

- Ion channels are proteins with conformations that can switch between 'closed', 'open' and inactivated/desensitized states (the gating process).

- Voltage-gated channels have intrinsic voltage-dependency; that is, their conformation is controlled by $\mathrm{V}_{\mathrm{m}}$. In addition, proteins which act as auxiliaries modulate accessory properties.

- $\mathrm{Na}^{+}, \mathrm{Ca}^{2+}$ and unselective cation channels tend to produce cell depolarization when open.

- $\mathrm{K}^{+}$channels tend to hyperpolarize the cell.

- The effect of $\mathrm{Cl}^{-}$channels is more unstable, because $[\mathrm{Cl}]$ i can greatly vary between different cell types.

- Many genes encoding mammalian voltage-gated channels are known. Nevertheless, when describing cellular currents, it is still habit to use the classic nomenclature. This defines broad functional features which account for different gene products that generate ion currents with similar (although not identical) properties.

Structural features of the voltage-gated channel superfamily:

- Voltage-gated $\mathrm{K}^{+}$channels are formed by four subunits surrounding a central pore. Each subunit is formed by six transmembrane segments (S1-S6). The $\mathrm{N}$ - and the $\mathrm{C}$ - terminus are intracellular. The S5 and S6 segments are connected by a pore loop, the latter controlling ion selectivity. The voltage-dependence is governed by the S1-S4 domains (VSD, voltage sensor domain).

- The intracellular domains contain consensus sequences for phosphorylation and the N-terminus determines interactions with other subunits or regulatory proteins.

- This pattern is also shared by $\mathrm{Na}^{+}$and $\mathrm{Ca}^{2+}$ channels, except that the four elements that surround the pore are not independent subunits, but are repeated domains of a continuous polypeptide; each domain is homologous to a $\mathrm{K}^{+}$channel subunit.

\section{Development of Antibodies Towards Ion Channels}

Ion channels include a very broad collection of structural and functional proteins. Such variety makes their targeting with antibodies a fascinating job. However, the design of antibodies against these structurally complex proteins is often challenging (Figure 2 and Box 1). In particular, the presence of short, poorly accessible extracellular loops (Figure 3) makes the identification of antibodies targeting ion channels from the extracellular side very complex work [111]. Overall, when developing an antibody towards an ion channel, several characteristics of the protein along with the difficulties in protein expression and manipulation, as well as in screening, must be taken into account [112]. Considering the above-mentioned issues, the development of monoclonal antibodies against ion channels still remains a challenge, justifying why only very few antibodies (Table 5) against those ion channels that are expressed in solid tumors have been developed so far [113].

The only example of an antibody targeting a cancer-related ion channel (the purinergic receptor P2X7) which has recently entered into the clinic with the potential to be approved as a first-generation therapy is BIL010t. BIL010t is a polyclonal antibody that targets a conformational epitope of the channel in its non-functional form (nfP2X7, Biosceptre). Given the hurdles faced in the aforementioned 
development of the antibody, some agonist antibodies against the same antigen were also developed. One of them is capable of inducing the cell death of P2X7-positive T cells, hence offering the possibility of a potential application for onco-immunotherapy [114]. Fully human antibodies targeting the Orai1 protein were raised through the immunization of the "Xenomouse" using U2OS cells overexpressing human Orai1 as immunogens. One of them was able to impair cell proliferation in peripheral blood human T lymphocytes [115,116]. In 2014, a well-conceived and simple strategy to isolate functional antibodies targeting the voltage-dependent $\mathrm{Na}^{+}$channel, Nav1.7, was published [117]. To this purpose, mice immunization was performed using a peptide (VELFLADVEG) located in the loop between the S3 and S4 helices in domain II (Box 1 and Figure 3). Although almost sixteen different antibodies were isolated against $\operatorname{TrpA} 1$, all showing high immunogenicity, their therapeutic potential was considered poor due to their lack of potency. A mAb against Eag1 was isolated immunizing mice with a fusion protein composed by residues 374-452 of the E3 loop between the S5-S6 transmembrane segments (i.e., the only scarce extracellular portion which might be exposed and thus targetable by an antibody). The latter was fused to the C-terminal tetramerization domain of the channel (residues 872-932) [118]. The molecule was able to inhibit Eag1 currents in HEK cells transfected with the channel and gave good results for the in vivo imaging of tumor xenografts but lacked biological activities. To induce apoptosis in Eag1-positive tumor cells, an anti-Eag1 scFv derived from the aforementioned $\mathrm{mAb}$ was joined to the tumor necrosis factor-related apoptosis-inducing ligand (TRAIL) [119]. This antibody, scFv62-TRAIL, was demonstrated to be a potential tool to overcome resistance to drugs. Overall, such findings demonstrate the possible application of these antibodies in cancer diagnosis as well as for targeted cancer therapy and theranostics [120].

Table 5. Ion channel-targeting antibody-based tools developed or under development. P2X7, ionotropic ATP-gated receptors; Eag-1, ether-à-go-go-1.

\begin{tabular}{|c|c|c|c|c|}
\hline Target & Ion Channel Type & Antibody Format & Assay & Reference \\
\hline $\mathrm{P} 2 \mathrm{X} 7$ & Ligand-gated & $\mathrm{mAb}$ & $\begin{array}{l}\text { Cell-binding assays, whole-cell } \\
\text { patch clamp and recognition of } \\
\text { native P2X7 }\end{array}$ & [114] \\
\hline Orai1 & $\begin{array}{l}\text { Calcium } \\
\text { release-activated } \\
\text { channel }\end{array}$ & $\mathrm{mAb}$ & $\begin{array}{l}\text { Cell-binding assays, store-operated } \\
\text { calcium influx, and } \\
\text { NFAT-dependent luciferase activity }\end{array}$ & [115] \\
\hline Orai1 & $\begin{array}{l}\text { Calcium } \\
\text { release-activated } \\
\text { channel }\end{array}$ & mAb peptide based & $\begin{array}{l}\text { ELISA cell-binding assays, calcium } \\
\text { flux, Orai1 internalization, and } \\
\text { T-cell proliferation }\end{array}$ & [116] \\
\hline TrpA1 & $\begin{array}{l}\text { Transient receptor } \\
\text { potential channel }\end{array}$ & $\mathrm{mAb}$ & $\begin{array}{l}\text { Cell-binding and radioactive } \\
\text { calcium uptake assay }\end{array}$ & [73] \\
\hline Nav1.7 & Voltage-gated & $\mathrm{mAb}$ & $\begin{array}{l}\text { ELISA using purified sensor domain } \\
\text { protein and whole-cell patch clamp }\end{array}$ & [117] \\
\hline Eag-1 & Voltage-gated & $\mathrm{mAb}$ & $\begin{array}{c}\text { ELISA and SPR, whole-cell patch } \\
\text { clamp }\end{array}$ & [119] \\
\hline \multirow[t]{2}{*}{ hERG1 } & $\begin{array}{l}\text { Voltage-gated } \mathrm{K}^{+} \\
\text {channel }\end{array}$ & $\mathrm{mAb}$ & $\begin{array}{c}\text { ELISA and SPR, whole-cell patch } \\
\text { clamp and IHC }\end{array}$ & [121] \\
\hline & “ & $\mathrm{scFv}$ & $\begin{array}{l}\text { ELISA and SPR, IHC ex vivo, } \\
\text { in vivo imaging }\end{array}$ & [122] \\
\hline hERG1/ $\beta 1$ & $\begin{array}{l}\text { Voltage-gated } \mathrm{K}^{+} \\
\text {channel }\end{array}$ & $\mathrm{scDb}$ & In vivo tumor targeting & [123] \\
\hline
\end{tabular}

\section{Ion Channels in Cancer Diagnostics: The Story of $K_{v} 11.1 / h E R G 1$}

One of the ion channels that is over-expressed and deregulated in human cancers is the voltage-dependent $\mathrm{K}^{+}$channel, $\mathrm{K}_{\mathrm{v}} 11.1$, also known as hERG1. In humans, hERG1 is physiologically expressed only in selected tissues: cardiac myocytes (where it contributes to the repolarizing potassium current $\mathrm{I}_{\mathrm{Kr}}$ ), pancreatic beta cells and neuronal cells of some selected areas of the CNS [49]. Since its first discovery in 1995 [86,124], hERG1 has been shown to be aberrantly expressed in human cancers of 
different histogenesis. In cancer cells, hERG1 modulates the main cancer-related intracellular signaling pathways (FAK, ERK, AKT, NFkB, HIF- $\alpha$, small GTPases, etc.) and hence drives many characteristics of neoplastic progression. Some examples, related to solid cancers, are reported in Table 5. Overall, many data were obtained both in vitro and in vivo, supporting the notion that hERG1 can be considered a novel cancer biomarker.

\subsection{Development of Anti-hERG1 Antibodies}

While only a few examples of antibodies targeting cancer-related ion channels [113] are detectable in literature so far, our research group has developed a mAb directed against hERG1, which turned out to be applicable for diagnostic purposes through IHC [88,91]. The hERG1-mAb was developed through the immunization of Balb/c mice following the Hybridoma Technology methodology and using a 14-amino acid synthetic peptide which encompasses the extracellular S5-P loop of the protein (highlighted in green in Figure 3). The specific sequence is EQPHMDSRIGWLHN. One out of the positive clones obtained from cell fusion, clone A12, showed the best performances in biological assays and was thus patented (patent Ref. $\mathrm{n}^{\circ}$ FI2006A000008). Thanks to the use of this antibody, strong scientific evidence has been provided demonstrating that hERG1 represents a novel cancer biomarker in patients with both solid cancers and hematologic malignancies [30,125]. A summary of the main clinical evidence obtained so far in solid cancer, especially those arising from the gastrointestinal tract, are detailed below.

\subsection{Evidence for hERG1 Being a Novel Tumor Biomarker for in Vitro Diagnostics (IVD)}

The hERG1-mAb has given encouraging results in different clinical studies, when more than 1500 human tumor samples were analyzed through IHC (see Table 5), reaching a high diagnostic and prognostic value for surgeons and clinical oncologists. The same antibody (and its engineered derivative described in paragraph 6.3) may have another clinical application in the endoscopic setting to detect hERG1 in pre-cancerous or cancerous lesions of GI tracts. In fact, hERG1 is over-expressed in Barrett's esophagus (BE), a precursor lesion for Esophageal Adenocarcinoma (EA), while absent in normal esophageal mucosa [95] and can identify patients with higher probability to malignant progression towards EA [97]. In other words, the hERG1 biomarker could identify high-risk BE patients and might be exploited for endoscopic surveillance of BE patients, thus allowing an early EA diagnosis.

hERG1 is also highly expressed in primary Gastric Cancer (GC): a study performed on 508 surgical samples showed a hERG1 immunoreactivity in 69\% of cases, with a statistically significant negative prognostic impact in early-stage GC and in precancerous lesions (gastric metaplasias and dysplasias) [96]. In particular, hERG1 expression in gastric metaplastic/dysplastic lesions could determine an innovative prognostic marker of progression towards GC of the intestinal histotype.

Much work has been done evaluating hERG1 expression in colorectal cancer (CRC). In the early stages, (TNM stage I and II) CRC hERG1 associates with Glut-1, VEGF-A, CA-IX, and EGFR, and behaves as an independent negative prognostic factor. In metastatic CRC (TNM stage IV), hERG1 represents a factor of positive response to anti-angiogenesis therapy (bevacizumab) [126]. In particular, hERG1-positive patients have a lower risk to progress during bevacizumab treatment. hERG1 can hence be proposed as a prognostic biomarker to identify patients to be treated with antiangiogenic agents, both in first- and second-line treatments.

In Pancreatic Ductal Adenocarcinoma (PDAC), hERG1 is expressed in roughly $60 \%$ of surgically resectable (TNM stages II and III) cases. By using our hERG1-mAb and applying a double scoring system, based on both signal intensity and percentage of labeled cells, a high hERG1 scoring was significantly associated with worse prognosis, both in the univariate and multivariate analysis. These results thus indicate hERG1 as an independent prognostic factor of worse prognosis in PDAC [88].

Finally, similar data were obtained by Pointer and colleagues [127], using the same mAb developed by our group. The authors concluded that hERG1 can be considered a potential Glioblastoma Multiforme (GBM) survival marker, since patients whose tumor was positive for hERG1 had a shorter survival 
compared to hERG1-negative cases. In addition, hERG1 behaved as a positive biomarker of therapy response, since those patients whose tumor was hERG1 positive and were treated with chemotherapy plus a hERG1 blocker (for the treatment of co-morbidities) had a longer survival compared to patients not treated with a hERG1 blocker. This finding led the authors to conclude that already approved hERG1 blockers might be considered as adjuvant therapy in high hERG1-expressing GBM patients [127].

All the above-mentioned results were obtained through IHC, using the anti-hERG1 mAb developed by us. Such a tool was hence very important to propose hERG1 as a potential prognostic marker. The translation potential of such data was corroborated by the possibility of detecting hERG1 in vivo, after its labeling with Alexa-680. In preclinical mouse models, the labeled mAb was able to identify hERG1-expressing PDAC tumors either in PDAC xenografts or in transgenic mice that develop tumor in the pancreas due to the expression of mutated Kras and Trp53 in pancreatic ductal cells [128]. Although, the anti-hERG1 mAb showed valuable proof of concept for in vivo use in preclinical mouse models, the antibody has been extensively implemented and has given promising results as an in vivo imaging tool after its engineering in the scFv format [122] (see below).

\subsection{Targeting hERG1 for Molecular Imaging}

Moving from the monoclonal antibody, we have developed a single-chain variable fragment antibody, anti-hERG1scFv. The antibody was mutagenized, substituting a phenylalanine residue in the third framework of the VH domain with a cysteine residue. The resulting scFv-hERG1-Cys showed much higher stability and protein yield, with better affinity and more advantageous binding kinetics, compared to the parental anti-hERG1scFv. The scFv-hERG1-Cys properly bound the native hERG1 antigen expressed on cells, was stable in serum, and displayed a fast pharmacokinetic profile (half-life of $3.1 \mathrm{~h}$ ) once injected intravenously in nude mice. Moreover, no general toxicity or cardiac toxic effects were detected. The in vivo distribution of an Alexa Fluor 750 conjugated scFv-hERG1-Cys showed a good tumor-to-organ ratio, ideal for visualizing hERG1-expressing tumor masses in vivo. Such findings allowed us to state that the scFv-hERG1-Cys possesses features which make it a suitable tool for application in cancer molecular imaging ([122], patent Ref: 102017000083637).

The $\mathrm{scFv}_{\mathrm{V}}$ was further developed in order to produce a bispecific antibody in the format of $\mathrm{scDb}$, directed against the hERG1- $\beta 1$ complex, which is a macromolecular complex formed between hERG1 and $\beta 1$ integrins which selectively occurs in cancers [102]. Such an antibody, once tested through IHC on both CRC and PDAC paraffin-embedded samples, confirmed its specificity for hERG1/ $\beta 1$ complex. Overall, the scDb-hERG1- $\beta 1$ antibody could be used as a potential new treatment for cancer patients and as an early molecular diagnostic marker, thus configured as one of the first examples of companion diagnostics targeting ion channels ([123], unpublished data).

\section{Conclusions and Future Perspectives}

Cancer diagnosis has been greatly affected by antibody application. The advent of a completenew class of antibodies, represented by recombinant antibodies with smaller sizes but retained specificities, has increased the possible uses of such a class of proteins for both cancer diagnosis and even for a theranostic approach to cancer. Considering possible novel biomarkers, ion channels are emerging as a new class of proteins and potential novel cancer biomarkers, since they are highly expressed in cancers and are involved in cancer establishment and progression. So far, due to the high complexity of such proteins, only a few antibodies have been developed against ion channels. Hence, there is still a lack of appropriate ion channel mAbs described in the literature and applied either in preclinical or in clinical trials. For these reasons, the example we propose in the present review regarding the antibodies developed against hERG1 by our group will also be remarkably interesting for market opportunities and new targets in the global clinical pipeline. 


\section{Patents}

In the present review, we have extensively reviewed the work accomplished using the antibodies patented under the following patent references, $\mathrm{n}^{\circ}$ FI2006A000008, patent Ref: 102017000083637. It is worth noting that the anti-hERG1 antibody developed by the University of Florence was licensed to MCK Therapeutics.

Author Contributions: Conceptualization, writing—original draft preparation, review and editing, C.D. and A.A.

Funding: This research was funded by AIRC 2015 grant n IG 15627, AIRC 2018 grant n IG 21510 and Omiterc Project "Applicazione degli OMIcs dalla biopsia solida alla biopsia liquida per una TERapia personalizzata del Cancro." Bando FAS 2014 to AA.

Acknowledgments: The authors want to acknowledge Elena Lastraioli and Jessica Iorio for their contribution in drafting Table 4. The authors also want to acknowledge Giovanni Navalesi.

Conflicts of Interest: A.A. is co-founder of MCK Therapeutics, a spin off of the University of Florence that owns the licence for patent $n^{\circ}$ FI2006A000008 and patent Ref: 102017000083637. C.D. declares no Conflicts of Interest. The funders had no role in the design of the study; in the collection, analyses, or interpretation of data; in the writing of the manuscript, or in the decision to publish the results.

\section{References}

1. Zhang, X.; Soori, G.; Dobleman, T.J.; Xiao, G.G. The application of monoclonal antibodies in cancer diagnosis. Expert Rev. Mol. Diagn. 2014, 14, 97-106. [CrossRef]

2. Scott, A.M.; Allison, J.P.; Wolchok, J.D. Monoclonal antibodies in cancer therapy. Cancer Immun. 2012, $12,14$. [PubMed]

3. Matsuhashi, N.; Takahashi, T.; Matsui, S.; Tanahashi, T.; Imai, H.; Tanaka, Y.; Yamaguchi, K.; Yoshida, K. A novel therapeutic strategy of personalized medicine based on anti-epidermal growth factor receptor monoclonal antibodies in patients with metastatic colorectal cancer. Int. J. Oncol. 2018, 52, 1391-1400. [CrossRef] [PubMed]

4. Moek, K.L.; Giesen, D.; Kok, I.C.; de Groot, D.J.A.; Jalving, M.; Fehrmann, R.S.N.; Lub-de Hooge, M.N.; Brouwers, A.H.; de Vries, E.G.E. Theranostics Using Antibodies and Antibody-Related Therapeutics. J. Nucl. Med. 2017, 58 (Suppl. 2), 83S-90S. [CrossRef]

5. Olsen, D.; Jørgensen, J.T. Companion diagnostics for targeted cancer drugs-Clinical and regulatory aspects. Front. Oncol. 2014, 4, 105. [CrossRef]

6. Ivell, R.; Teerds, K.; Hoffman, G.E. Proper application of antibodies for immunohistochemical detection: Antibody crimes and how to prevent them. Endocrinology 2014, 155, 676-687. [CrossRef]

7. Finotello, F.; Eduati, F. Multi-Omics Profiling of the Tumor Microenvironment: Paving the Way to Precision Immuno-Oncology. Front. Oncol. 2018, 8, 430. [CrossRef] [PubMed]

8. Su, Y.; Shi, Q.; Wei, W. Single cell proteomics in biomedicine: High-dimensional data acquisition, visualization, and analysis. Proteomics 2017, 17, 1600267. [CrossRef] [PubMed]

9. Li, K.; Tavaré, R.; Zettlitz, K.A.; Mumenthaler, S.M.; Mallick, P.; Zhou, Y.; Marks, J.D.; Wu, A.M. Anti-MET immunoPET for non-small cell lung cancer using fully human antibody fragments. Mol. Cancer Ther. 2014, 13, 2607-2617. [CrossRef] [PubMed]

10. Korb, M.L.; Hartman, Y.E.; Kovar, J.; Zinn, K.R.; Bland, K.I.; Rosenthal, E.L. Use of monoclonal antibody-irdye $800 \mathrm{cw}$ bioconjugates in the resection of breast cancer. J. Surg. Res. 2014, 188, 119-128. [CrossRef] [PubMed]

11. Day, K.E.; Sweeny, L.; Kulbersh, B.; Zinn, K.R.; Rosenthal, E.L. Preclinical comparison of near-infrared-labeled cetuximab and panitumumab for optical imaging of head and neck squamous cell carcinoma. Mol. Imaging Biol. 2013, 15, 722-729. [CrossRef] [PubMed]

12. Holliger, P.; Hudson, P.J. Engineered antibody fragments and the rise of single domains. Nat. Biotechnol. 2005, 23, 1126-1136. [CrossRef] [PubMed]

13. James, M.L.; Gambhir, S.S. A molecular imaging primer: Modalities, imaging agents, and applications. Physiol. Rev. 2012, 92. [CrossRef]

14. Knowles, S.M.; Wu, A.M. Advances in immuno-positron emission tomography: Antibodies for molecular imaging in oncology. J. Clin. Oncol. 2012, 30, 3884-3892. [CrossRef] [PubMed] 
15. Arslan, M.; Karadă̆, D.; Kalyoncu, S. Protein engineering approaches for antibody fragments: Directed evolution and rational design approaches. Turk. J. Biol. 2019, 43, 1-12. [CrossRef] [PubMed]

16. Massa, S.; Xavier, C.; De Vos, J.; Caveliers, V.; Lahoutte, T.; Muyldermans, S.; Devoogdt, N. Site-specific labeling of cysteine-tagged camelid single-domain antibody-fragments for use in molecular imaging. Bioconjug. Chem. 2014, 25, 979-988. [CrossRef] [PubMed]

17. Schoonooghe, S.; Laoui, D.; Van Ginderachter, J.A.; Devoogdt, N.; Lahoutte, T.; De Baetselier, P.; Raes, G. Novel applications of nanobodies for in vivo bio-imaging of inflamed tissues in inflammatory diseases and cancer. Immunobiology 2012, 217. [CrossRef] [PubMed]

18. Desplancq, D.; King, D.J.; Lawson, A.D.; Mountain, A. Multimerization behaviour of single chain Fv variants for the tumour-binding antibody B72.3. Protein Eng. 1994, 7, 1027-1033. [CrossRef]

19. Suurs, F.V.; Lub-de Hooge, M.N.; de Vries, E.G.E.; de Groot, D.J.A. A review of bispecific antibodies and antibody constructs in oncology and clinical challenges. Pharmacol. Ther. 2019. [CrossRef]

20. Viola-Villegas, N.T.; Sevak, K.K.; Carlin, S.D.; Doran, M.G.; Evans, H.W.; Bartlett, D.W.; Wu, A.M.; Lewis, J.S. Noninvasive imaging of PSMA in prostate tumors with 89Zr-Labeled huJ591 engineered antibody fragments: The faster alternatives. Mol. Pharm. 2014, 11. [CrossRef]

21. Bannas, P.; Well, L.; Lenz, A.; Rissiek, B.; Haag, F.; Schmid, J.; Hochgräfe, K.; Trepel, M.; Adam, G.; Ittrich, H.; Koch-Nolte, F. In vivo near-infrared fluorescence targeting of T cells: Comparison of nanobodies and conventional monoclonal antibodies. Contrast Media Mol. Imaging. 2014, 9. [CrossRef]

22. Zielinski, R.; Hassan, M.; Lyakhov, I.; Needle, D.; Chernomordik, V.; Garcia-Glaessner, A.; Ardeshirpour, Y.; Capala, J.; Gandjbakhche, A. Affibody-DyLight conjugates for in vivo assessment of HER2 expression by near-infrared optical imaging. PLoS ONE 2012, 7, e41016. [CrossRef]

23. Iezzi, M.E.; Policastro, L.; Werbajh, S.; Podhajcer, O.; Canziani, G.A. Single-Domain Antibodies and the Promise of Modular Targeting in Cancer Imaging and Treatment. Front. Immunol. 2018, 9, 273. [CrossRef]

24. Kwon, L.Y.; Scollard, D.A.; Reilly, R.M. 64Cu-labeled trastuzumab fab-PEG24-EGF radioimmunoconjugates bispecific for HER2 and EGFR: Pharmacokinetics, biodistribution, and tumor imaging by PET in comparison to monospecific agents. Mol. Pharm. 2017, 14, 492-501. [CrossRef]

25. Ogasawara, A.; Tinianow, J.N.; Vanderbilt, A.N.; Gill, H.S.; Yee, S.; Flores, J.E.; Williams, S.P.; Ashkenazi, A.; Marik, J. ImmunoPET imaging of phosphatidylserine in pro-apoptotic therapy treated tumor models. Nucl. Med. Biol. 2013, 40, 15-22. [CrossRef]

26. Razumienko, E.; Dryden, L.; Scollard, D.; Reilly, R.M. MicroSPECT/CT imaging of co-expressed HER2 and EGFR on subcutaneous human tumor xenografts in athymic mice using 111In-labeled bispecific radioimmunoconjugates. Breast Cancer Res Treat. 2013, 138, 709-718. [CrossRef]

27. Prevarskaya, N.; Skryma, R.; Shuba, Y. Ion Channels in Cancer: Are Cancer Hallmarks Oncochannelopathies? Physiol. Rev. 2018, 98, 559-621. [CrossRef] [PubMed]

28. Arcangeli, A.; Becchetti, A. Complex functional interaction between integrin receptors and ion channels. Trends Cell Biol. 2006, 16, 631-639. [CrossRef]

29. Becchetti, A.; Petroni, G.; Arcangeli, A. Ion Channel Conformations Regulate Integrin-Dependent Signaling. Trends Cell Biol. 2019, 29, 298-307. [CrossRef] [PubMed]

30. Arcangeli, A.; Crociani, O.; Lastraioli, E.; Masi, A.; Pillozzi, S.; Becchetti, A. Targeting ion channels in cancer: A novel frontier in antineoplastic therapy. Curr. Med. Chem. 2009, 16, 66-93. [CrossRef] [PubMed]

31. Lastraioli, E.; Iorio, J.; Arcangeli, A. Ion channel expression as promising cancer biomarker. Biochim. Biophys. Acta 2015, 1848, 2685-2702. [CrossRef]

32. Ding, X.W.; Yan, J.J.; An, P.; Lü, P.; Luo, H.S. Aberrant expression of ether à go-go potassium channel in colorectal cancer patients and cell lines. World J. Gastroenterol. 2007, 13, 1257-1261. [CrossRef]

33. Fraser, S.P.; Grimes, J.A.; Diss, J.K.; Stewart, D.; Dolly, J.O.; Djamgoz, M.B. Predominant expression of Kv1.3 voltage-gated $\mathrm{K}+$ channel subunit in rat prostate cancer cell lines: Electrophysiological, pharmacological and molecular characterisation. Pflugers Arch. 2003, 446, 559-571. [CrossRef] [PubMed]

34. Ota, M.; Ito, T.; Umemura, T.; Katsuyama, Y.; Yoshizawa, K.; Hamano, H.; Kawa, S. Polymorphism in the KCNA3 gene is associated with susceptibility to autoimmune pancreatitis in the Japanese population. Dis. Markers. 2011, 31, 223-229. [CrossRef] [PubMed]

35. Zhong, X.; Lü, M.; Wan, J.; Zhou, T.; Qin, B. Long noncoding RNA kcna3 inhibits the progression of colorectal carcinoma through down-regulating YAP1 expression. Biomed. Pharmacother. 2018, 107, 382-389. [CrossRef] [PubMed] 
36. Hauptman, N.; Jevšinek Skok, D.; Spasovska, E.; Boštjančič, E.; Glavač, D. Genes CEP55, FOXD3, FOXF2, GNAO1, GRIA4, and KCNA5 as potential diagnostic biomarkers in colorectal cancer. BMC Med. Genom. 2019, 12, 54. [CrossRef]

37. Dong, Z.; Yang, P.; Qiu, X.; Liang, S.; Guan, B.; Yang, H.; Li, F.; Sun, L.; Liu, H.; Zou, G.; Zhao, K. KCNQ1OT1 facilitates progression of non-small-cell lung carcinoma via modulating miRNA-27b-3p/HSP90AA1 axis. J. Cell Physiol. 2019, 234, 11304-11314. [CrossRef]

38. Oeggerli, M.; Tian, Y.; Ruiz, C.; Wijker, B.; Sauter, G.; Obermann, E.; Güth, U.; Zlobec, I.; Sausbier, M.; Kunzelmann, K.; Bubendorf, L. Role of KCNMA1 in breast cancer. PLoS ONE 2012, 7, e41664. [CrossRef]

39. Bloch, M.; Ousingsawat, J.; Simon, R.; Schraml, P.; Gasser, T.C.; Mihatsch, M.J.; Kunzelmann, K.; Bubendorf, L. KCNMA1 gene amplification promotes tumor cell proliferation in human prostate cancer. Oncogene 2007, 26, 2525-2534. [CrossRef]

40. Liu, Y.; Walavalkar, N.M.; Dozmorov, M.G.; Rich, S.S.; Civelek, M.; Guertin, M.J. Identification of breast cancer associated variants that modulate transcription factor binding. PLoS Genet. 2017, 13, e1006761. [CrossRef]

41. Jiang, S.; Zhu, L.; Yang, J.; Hu, L.; Gu, J.; Xing, X.; Sun, Y.; Zhang, Z. Integrated expression profiling of potassium channels identifys KCNN4 as a prognostic biomarker of pancreatic cancer. Biochem. Biophys. Res. Commun. 2017, 494, 113-119. [CrossRef]

42. He, T.; Wang, C.; Zhang, M.; Zhang, X.; Zheng, S.; Linghu, E.; Guo, M. Epigenetic regulation of voltage-gated potassium ion channel molecule Kv1.3 in mechanisms of colorectal cancer. Discov. Med. 2017, 23, 155-162.

43. Huang, X.; Jan, L.Y. Targeting potassium channels in cancer. J. Cell Biol. 2014, 206, 151-162. [CrossRef]

44. Kammerer, S.; Sokolowski, A.; Hackl, H.; Platzer, D.; Jahn, S.W.; El-Heliebi, A.; Schwarzenbacher, D.; Stiegelbauer, V.; Pichler, M.; Rezania, S.; et al. KCNJ3 is a new independent prognostic marker for estrogen receptor positive breast cancer patients. Oncotarget 2016, 7, 84705-84717. [CrossRef]

45. Alvarez-Baron, C.P.; Jonsson, P.; Thomas, C.; Dryer, S.E.; Williams, C. The two-pore domain potassium channel KCNK5: Induction by estrogen receptor alpha and role in proliferation of breast cancer cells. Mol. Endocrinol. 2011, 25, 1326-1336. [CrossRef]

46. Dookeran, K.A.; Zhang, W.; Stayner, L.; Argos, M. Associations of two-pore domain potassium channels and triple negative breast cancer subtype in The Cancer Genome Atlas: Systematic evaluation of gene expression and methylation. BMC Res. Notes 2017, 10, 475. [CrossRef]

47. Kim, C.J.; Cho, Y.G.; Jeong, S.W.; Kim, Y.S.; Kim, S.Y.; Nam, S.W.; Lee, S.H.; Yoo, N.J.; Lee, J.Y.; Park, W.S. Altered expression of KCNK9 in colorectal cancers. APMIS 2004, 112, 588-594. [CrossRef]

48. Yamaci, R.F.; Fraser, S.P.; Battaloglu, E.; Kaya, H.; Erguler, K.; Foster, C.S.; Djamgoz, M.B.A. Neonatal Nav1.5 protein expression in normal adult human tissues and breast cancer. Pathol. Res. Pract. 2017, 213, 900-907. [CrossRef]

49. Guzel, R.M.; Ogmen, K.; Ilieva, K.M.; Fraser, S.P.; Djamgoz, M.B.A. Colorectal cancer invasiveness in vitro: Predominant contribution of neonatal Nav1.5 under normoxia and hypoxia. J. Cell Physiol. 2019, 234, 6582-6593. [CrossRef]

50. Chen, B.; Zhang, C.; Wang, Z.; Chen, Y.; Xie, H.; Li, S.; Liu, X.; Liu, Z.; Chen, P. Mechanistic insights into Nav1.7-dependent regulation of rat prostate cancer cell invasiveness revealed by toxin probes and proteomic analysis. FEBS J. 2019. [CrossRef]

51. Campbell, T.M.; Main, M.J.; Fitzgerald, E.M. Functional expression of the voltage-gated $\mathrm{Na}^{+}$-channel Nav1.7 is necessary for EGF-mediated invasion in human non-small cell lung cancer cells. J. Cell Sci. 2013, 126, 4939-4949. [CrossRef]

52. Gao, B.; Sekido, Y.; Maximov, A.; Saad, M.; Forgacs, E.; Latif, F.; Wei, M.H.; Lerman, M.; Lee, J.H.; Perez-Reyes, E.; Bezprozvanny, I.; Minna, J.D. Functional properties of a new voltage-dependent calcium channel alpha(2)delta auxiliary subunit gene (CACNA2D2). J. Biol. Chem. 2000, 275, 12237-12242. [CrossRef]

53. Mariot, P.; Vanoverberghe, K.; Lalevee, N.; Rossier, M.F.; Prevarskaya, N. Overexpression of an alpha $1 \mathrm{H}$ (Cav3.2) T-type calcium channel during neuroendocrine differentiation of human prostate cancer cells. J. Biol. Chem. 2002, 277, 10824-10833. [CrossRef]

54. Wanajo, A.; Sasaki, A.; Nagasaki, H.; Shimada, S.; Otsubo, T.; Owaki, S.; Shimizu, Y.; Eishi, Y.; Kojima, K.; Nakajima, Y.; et al. Methylation of the calcium channel-related gene, CACNA2D3, is frequent and a poor prognostic factor in gastric cancer. Gastroenterology 2008, 135, 580-590. [CrossRef]

55. Jin, Y.; Cui, D.; Ren, J.; Wang, K.; Zeng, T.; Gao, L. CACNA2D3 is downregulated in gliomas and functions as a tumor suppressor. Mol. Carcinog. 2017, 56, 945-959. [CrossRef] 
56. Peters, A.A.; Milevskiy, M.J.; Lee, W.C.; Curry, M.C.; Smart, C.E.; Saunus, J.M.; Reid, L.; da Silva, L.; Marcial, D.L.; Dray, E.; et al. The calcium pump plasma membrane Ca(2+)-ATPase 2 (PMCA2) regulates breast cancer cell proliferation and sensitivity to doxorubicin. Sci. Rep. 2016, 6, 25505. [CrossRef]

57. Yang, S.; Zhang, J.J.; Huang, X.Y. Orai1 and STIM1 are critical for breast tumor cell migration and metastasis. Cancer Cell. 2009, 15, 124-134. [CrossRef]

58. Lee, S.H.; Rigas, N.K.; Lee, C.R.; Bang, A.; Srikanth, S.; Gwack, Y.; Kang, M.K.; Kim, R.H.; Park, N.H.; Shin, K.H. Orai1 promotes tumor progression by enhancing cancer stemness via NFAT signaling in oral/oropharyngeal squamous cell carcinoma. Oncotarget 2016, 7, 43239-43255. [CrossRef]

59. Hasna, J.; Hague, F.; Rodat-Despoix, L.; Geerts, D.; Leroy, C.; Tulasne, D.; Ouadid-Ahidouch, H.; Kischel, P. Orai3 calcium channel and resistance to chemotherapy in breast cancer cells: The p53 connection. Cell Death Differ. 2018, 25, 691-705. [CrossRef] [PubMed]

60. Benzerdjeb, N.; Sevestre, H.; Ahidouch, A.; Ouadid-Ahidouch, H. Orai3 is a predictive marker of metastasis and survival in resectable lung adenocarcinoma. Oncotarget 2016, 7, 81588-81597. [CrossRef]

61. Sauter, D.R.P.; Novak, I.; Pedersen, S.F.; Larsen, E.H.; Hoffmann, E.K. ANO1 (TMEM16A) in pancreatic ductal adenocarcinoma (PDAC). Pflugers Arch. 2015, 467, 1495-1508. [CrossRef]

62. Li, X.; Hu, W.; Zhou, J.; Huang, Y.; Peng, J.; Yuan, Y.; Yu, J.; Zheng, S. CLCA1 suppresses colorectal cancer aggressiveness via inhibition of the Wnt/beta-catenin signaling pathway. Cell Commun. Signal. 2017, 15, 38. [CrossRef]

63. Li, X.; Cowell, J.K.; Sossey-Alaoui, K. CLCA2 tumour suppressor gene in 1p31 is epigenetically regulated in breast cancer. Oncogene 2004, 23, 1474-1480. [CrossRef]

64. Bustin, S.A.; Li, S.R.; Dorudi, S. Expression of the Ca2+-activated chloride channel genes CLCA1 and CLCA2 is downregulated in human colorectal cancer. DNA Cell Biol. 2001, 20, 331-338. [CrossRef]

65. Wang, P.; Zhang, C.; Yu, P.; Tang, B.; Liu, T.; Cui, H.; Xu, J. Regulation of colon cancer cell migration and invasion by CLIC1-mediated RVD. Mol. Cell Biochem. 2012, 365, 313-321. [CrossRef]

66. Chen, C.D.; Wang, C.S.; Huang, Y.H.; Chien, K.Y.; Liang, Y.; Chen, W.J.; Lin, K.H. Overexpression of CLIC1 in human gastric carcinoma and its clinicopathological significance. Proteomics 2007, 7, 155-167. [CrossRef]

67. Macpherson, I.R.; Rainero, E.; Mitchell, L.E.; van den Berghe, P.V.; Speirs, C.; Dozynkiewicz, M.A.; Chaudhary, S.; Kalna, G.; Edwards, J.; Timpson, P.; et al. CLIC3 controls recycling of late endosomal MT1-MMP and dictates invasion and metastasis in breast cancer. J. Cell Sci. 2014, 127, 3893-3901. [CrossRef]

68. Chodon, D.; Guilbert, A.; Dhennin-Duthille, I.; Gautier, M.; Telliez, M.S.; Sevestre, H.; Ouadid-Ahidouch, H. Estrogen regulation of TRPM8 expression in breast cancer cells. BMC Cancer 2010, 10, 212. [CrossRef] [PubMed]

69. Zhang, L.; Barritt, G.J. TRPM8 in prostate cancer cells: A potential diagnostic and prognostic marker with a secretory function? Endocr. Relat. Cancer 2006, 13, 27-38. [CrossRef]

70. Yee, N.S. TRPM8 Ion Channels as Potential Cancer Biomarker and Target in Pancreatic Cancer. Adv. Protein. Chem. Struct. Biol. 2016, 104, 127-155. [CrossRef]

71. Kuipers, A.J.; Middelbeek, J.; Vrenken, K.; Pérez-González, C.; Poelmans, G.; Klarenbeek, J.; Jalink, K.; Trepat, X.; van Leeuwen, F.N. TRPM7 controls mesenchymal features of breast cancer cells by tensional regulation of SOX4. Biochim. Biophys. Acta Mol. Basis Dis. 2018, 1864, 2409-2419. [CrossRef] [PubMed]

72. Yee, N.S.; Chan, A.S.; Yee, J.D.; Yee, R.K. TRPM7 and TRPM8 Ion Channels in Pancreatic Adenocarcinoma: Potential Roles as Cancer Biomarkers and Targets. Scientifica (Cairo) 2012, 2012, 415158. [CrossRef] [PubMed]

73. Büch, T.R.H.; Büch, E.A.M.; Boekhoff, I.; Steinritz, D.; Aigner, A. Role of Chemosensory TRP Channels in Lung Cancer. Pharmaceuticals (Basel) 2018, 11. [CrossRef] [PubMed]

74. Azimi, I.; Milevskiy, M.J.G.; Kaemmerer, E.; Turner, D.; Yapa, K.T.D.S.; Brown, M.A.; Thompson, E.W.; Roberts-Thomson, S.J.; Monteith, G.R. TRPC1 is a differential regulator of hypoxia-mediated events and Akt signalling in PTEN-deficient breast cancer cells. J. Cell Sci. 2017, 130, 2292-2305. [CrossRef]

75. Zhang, J.; Zhu, Z.; Li, X.W.; Zhang, Z.F. Knocking down TRPC1 expression by siRNA inhibits proliferation and invasiveness of human lung adenocarcinoma cell A549 in vitro. Zhonghua Yi Xue Za Zhi 2013, 93, 2241-2243.

76. Wang, Y.; Qi, Y.X.; Qi, Z.; Tsang, S.Y. TRPC3 Regulates the Proliferation and Apoptosis Resistance of Triple Negative Breast Cancer Cells through the TRPC3/RASA4/MAPK Pathway. Cancers (Basel) 2019, 11. [CrossRef] 
77. Jiang, H.N.; Zeng, B.; Zhang, Y.; Daskoulidou, N.; Fan, H.; Qu, J.M.; Xu, S.Z. Involvement of TRPC channels in lung cancer cell differentiation and the correlation analysis in human non-small cell lung cancer. PLOS ONE 2013, 8, e67637. [CrossRef]

78. Yang, L.L.; Liu, B.C.; Lu, X.Y.; Yan, Y.; Zhai, Y.J.; Bao, Q.; Doetsch, P.W.; Deng, X.; Thai, T.L.; Alli, A.A.; Eaton, D.C.; Shen, B.Z.; Ma, H.P. Inhibition of TRPC6 reduces non-small cell lung cancer cell proliferation and invasion. Oncotarget 2017, 8, 5123-5134. [CrossRef]

79. Shi, Y.; Ding, X.; He, Z.H.; Zhou, K.C.; Wang, Q.; Wang, Y.Z. Critical role of TRPC6 channels in G2 phase transition and the development of human oesophageal cancer. Gut 2009, 58, 1443-1450. [CrossRef]

80. Schwartz, E.S.; La, J.H.; Scheff, N.N.; Davis, B.M.; Albers, K.M.; Gebhart, G.F. TRPV1 and TRPA1 antagonists prevent the transition of acute to chronic inflammation and pain in chronic pancreatitis. J. Neurosci. 2013, 33, 5603-5611. [CrossRef]

81. Lee, W.H.; Choong, L.Y.; Mon, N.N.; Lu, S.; Lin, Q.; Pang, B.; Yan, B.; Krishna, V.S.; Singh, H.; Tan, T.Z.; et al. TRPV4 Regulates Breast Cancer Cell Extravasation, Stiffness and Actin Cortex. Sci. Rep. 2016, 6, 27903. [CrossRef]

82. Wissenbach, U.; Niemeyer, B.; Himmerkus, N.; Fixemer, T.; Bonkhoff, H.; Flockerzi, V. TRPV6 and prostate cancer: Cancer growth beyond the prostate correlates with increased TRPV6 $\mathrm{Ca}^{2+}$ channel expression. Biochem. Biophys. Res. Commun. 2004, 322, 1359-1363. [CrossRef] [PubMed]

83. Fernández-Valle, Á.; Rodrigo, J.P.; Rodríguez-Santamarta, T.; Villaronga, M.Á.; Álvarez-Teijeiro, S.; García-Pedrero, J.M.; Suárez-Fernández, L.; Lequerica-Fernández, P.; de Vicente, J.C. HERG1 potassium channel expression in potentially malignant disorders of the oral mucosa and prognostic relevance in oral squamous cell carcinoma. Head Neck 2016, 38, 1672-1678. [CrossRef]

84. Menéndez, S.T.; Villaronga, M.Á.; Rodrigo, J.P.; Álvarez-Teijeiro, S.; Urdinguio, R.G.; Fraga, M.F.; Suárez, C.; García-Pedrero, J.M. HERG1A potassium channel is the predominant isoform in head and neck squamous cell carcinomas: Evidence for regulation by epigenetic mechanisms. Sci. Rep. 2016, 6, 19666. [CrossRef] [PubMed]

85. Masi, A.; Becchetti, A.; Restano-Cassulini, R.; Polvani, S.; Hofmann, G.; Buccoliero, A.M.; Paglierani, M.; Pollo, B.; Taddei, G.L.; Gallina, P.; et al. hERG1 channels are overexpressed in glioblastoma multiforme and modulate VEGF secretion in glioblastoma cell lines. Br. J. Cancer 2005, 93, 781-792. [CrossRef]

86. Arcangeli, A.; Bianchi, L.; Becchetti, A.; Faravelli, L.; Coronnello, M.; Mini, E.; Olivotto, M.; Wanke, E.A. novel inward-rectifying $\mathrm{K}+$ current with a cell-cycle dependence governs the resting potential of mammalian neuroblastoma cells. J. Physiol. 1995, 489, 455-471. [CrossRef] [PubMed]

87. Glassmeier, G.; Hempel, K.; Wulfsen, I.; Bauer, C.K.; Schumacher, U.; Schwarz, J.R. Inhibition of HERG1 K+ channel protein expression decreases cell proliferation of human small cell lung cancer cells. Pflugers Arch. 2012, 463, 365-376. [CrossRef]

88. Lastraioli, E.; Perrone, G.; Sette, A.; Fiore, A.; Crociani, O.; Manoli, S.; D’Amico, M.; Masselli, M.; Iorio, J.; Callea, M.; et al. hERG1 channels drive tumour malignancy and may serve as prognostic factor in pancreatic ductal adenocarcinoma. Br. J. Cancer. 2015, 112, 1076-1087. [CrossRef]

89. Feng, J.; Yu, J.; Pan, X.; Li, Z.; Chen, Z.; Zhang, W.; Wang, B.; Yang, L.; Xu, H.; Zhang, G.; Xu, Z. HERG1 functions as an oncogene in pancreatic cancer and is downregulated by miR-96. Oncotarget 2014, 5, 5832-5844. [CrossRef]

90. Zhi, D.; Zhao, X.; Dong, M.; Yan, C. miR-493 inhibits proliferation and invasion in pancreatic cancer cells and inversely regulated hERG1 expression. Oncol. Lett. 2017, 14, 7398-7404. [CrossRef]

91. Lastraioli, E.; Bencini, L.; Bianchini, E.; Romoli, M.R.; Crociani, O.; Giommoni, E.; Messerini, L.; Gasperoni, S.; Moretti, R.; Di Costanzo, F.; Boni, L.; Arcangeli, A. hERG1 Channels and Glut-1 as Independent Prognostic Indicators of Worse Outcome in Stage I and II Colorectal Cancer: A Pilot Study. Transl. Oncol. 2012, 5, 105-112. [CrossRef] [PubMed]

92. Lastraioli, E.; Guasti, L.; Crociani, O.; Polvani, S.; Hofmann, G.; Witchel, H.; Bencini, L.; Calistri, M.; Messerini, L.; Scatizzi, M.; et al. herg1 gene and HERG1 protein are overexpressed in colorectal cancers and regulate cell invasion of tumor cells. Cancer Res. 2004, 64, 606-611. [CrossRef]

93. Muratori, L.; Petroni, G.; Antonuzzo, L.; Boni, L.; Iorio, J.; Lastraioli, E.; Bartoli, G.; Messerini, L.; Di Costanzo, F.; Arcangeli, A. hERG1 positivity and Glut-1 negativity identifies high-risk TNM stage I and II colorectal cancer patients, regardless of adjuvant chemotherapy. Onco Targets Ther. 2016, 9, 6325-6332. [CrossRef] 
94. Iorio, J.; Lastraioli, E.; Tofani, L.; Petroni, G.; Antonuzzo, L.; Messerini, L.; Perrone, G.; Caputo, D.; Francesconi, M.; Amato, M.M.; et al. A signalling pathway centred on hERG1 potassium channel identifies metastatic colorectal cancer patients with a positive response to Bevacizumab. (Submitted to International Journal of Cancer).

95. Lastraioli, E.; Taddei, A.; Messerini, L.; Comin, C.E.; Festini, M.; Giannelli, M.; Tomezzoli, A.; Paglierani, M.; Mugnai, G.; De Manzoni, G.; et al. hERG1 channels in human esophagus: Evidence for their aberrant expression in the malignant progression of Barrett's esophagus. J. Cell Physiol. 2006, 209, 398-404. [CrossRef]

96. Lastraioli, E.; Lottini, T.; Iorio, J.; Freschi, G.; Fazi, M.; Duranti, C.; Carraresi, L.; Messerini, L.; Taddei, A.; Ringressi, M.N.; et al. hERG1 behaves as biomarker of progression to adenocarcinoma in Barrett's esophagus and can be exploited for a novel endoscopic surveillance. Oncotarget 2016, 7, 59535-59547. [CrossRef]

97. Crociani, O.; Lastraioli, E.; Boni, L.; Pillozzi, S.; Romoli, M.R.; D'Amico, M.; Stefanini, M.; Crescioli, S.; Masi, A.; Taddei, A.; et al. hERG1 channels regulate VEGF-A secretion in human gastric cancer: Clinicopathological correlations and therapeutical implications. Clin. Cancer Res. 2014, 20, 1502-1512. [CrossRef]

98. Shao, X.D.; Wu, K.C.; Guo, X.Z.; Xie, M.J.; Zhang, J.; Fan, D.M. Expression and significance of HERG protein in gastric cancer. Cancer Biol. Ther. 2008, 7, 45-50. [CrossRef]

99. Ding, X.W.; Yang, W.B.; Gao, S.; Wang, W.; Li, Z.; Hu, W.M.; Li, J.J.; Luo, H.S. Prognostic significance of hERG1 expression in gastric cancer. Dig. Dis. Sci. 2010, 55, 1004-1010. [CrossRef]

100. Zhang, R.; Tian, P.; Chi, Q.; Wang, J.; Wang, Y.; Sun, L.; Liu, Y.; Tian, S.; Zhang, Q. Human ether-à-go-go-related gene expression is essential for cisplatin to induce apoptosis in human gastric cancer. Oncol. Rep. 2012, 27, 433-440.

101. Antonuzzo, L.; Iorio, J.; Lastraioli, E.; Tofani, L.; Laffi, A.; Antonelli, A.; Messerini, L.; Boni, L.; Di Costanzo, F.; Arcangeli, A. hERG1 in pancreatic neuroendocrine cancers. (Manuscript in preparation).

102. Becchetti, A.; Crescioli, S.; Zanieri, F.; Petroni, G.; Mercatelli, R.; Coppola, S.; Gasparoli, L.; D'Amico, M.; Pillozzi, S.; Crociani, O.; et al. The conformational state of hERG1 channels determines integrin association, downstream signaling, and cancer progression. Sci. Signal. 2017, 10, eaaf3236. [CrossRef]

103. Iorio, J.; Meattini, I.; Bianchi, S.; Bernini, M.; Maragna, V.; Dominici, L.; Casella, D.; Vezzosi, V.; Orzalesi, L.; Nori, J.; et al. hERG1 channel expression associates with molecular subtypes and prognosis in breast cancer. Cancer Cell Int. 2018, 18, 93. [CrossRef]

104. Cherubini, A.; Taddei, G.L.; Crociani, O.; Paglierani, M.; Buccoliero, A.M.; Fontana, L.; Noci, I.; Borri, P.; Borrani, E.; Giachi, M.; et al. HERG potassium channels are more frequently expressed in human endometrial cancer as compared to non-cancerous endometrium. Br. J. Cancer. 2000, 83, 1722-1729. [CrossRef] [PubMed]

105. Asher, V.; Khan, R.; Warren, A.; Shaw, R.; Schalkwyk, G.V.; Bali, A.; Sowter, H.M. The Eag potassium channel as a new prognostic marker in ovarian cancer. Diagn. Pathol. 2010, 5, 78. [CrossRef] [PubMed]

106. Asher, V.; Warren, A.; Shaw, R.; Sowter, H.; Bali, A.; Khan, R. The role of Eag and HERG channels in cell proliferation and apoptotic cell death in SK-OV-3 ovarian cancer cell line. Cancer Cell Int. 2011, 11, 6. [CrossRef] [PubMed]

107. Cicek, M.S.; Koestler, D.C.; Fridley, B.L.; Kalli, K.R.; Armasu, S.M.; Larson, M.C.; Wang, C.; Winham, S.J.; Vierkant, R.A.; Rider, D.N.; et al. Epigenome-wide ovarian cancer analysis identifies a methylation profile differentiating clear-cell histology with epigenetic silencing of the HERG K+ channel. Hum. Mol. Genet. 2013, 22, 3038-3047. [CrossRef] [PubMed]

108. Afrasiabi, E.; Hietamäki, M.; Viitanen, T.; Sukumaran, P.; Bergelin, N.; Törnquist, K. Expression and significance of HERG (KCNH2) potassium channels in the regulation of MDA-MB-435S melanoma cell proliferation and migration. Cell Signal. 2010, 22, 57-64. [CrossRef]

109. Arcangeli, A.; Romoli, M.R.; Boni, L.; Gerlini, G.; Tofani, L.; Urso, C.; Borgognoni, L. High hERG1 expression in advanced melanoma. Melanoma Res. 2013, 23, 185-190. [CrossRef]

110. Zeng, W.; Liu, Q.; Chen, Z.; Wu, X.; Zhong, Y.; Wu, J. Silencing of hERG1 Gene Inhibits Proliferation and Invasion, and Induces Apoptosis in Human Osteosarcoma Cells by Targeting the NF-kB Pathway. J. Cancer. 2016, 7, 746-757. [CrossRef]

111. Wilkinson, T.C.; Gardener, M.J.; Williams, W.A. Discovery of functional antibodies targeting ion channels. J. Biomol. Screen. 2015, 20, 454-467. [CrossRef]

112. Sun, H.; Li, M. Antibody therapeutics targeting ion channels: Are we there yet? Acta Pharmacol. Sin. 2013, 34, 199-204. [CrossRef] 
113. Hutchings, C.J.; Colussi, P.; Clark, T.G. Ion channels as therapeutic antibody targets. MAbs 2019, 11, $265-296$. [CrossRef]

114. Buell, G.; Chessell, I.P.; Michel, A.D.; Collo, G.; Salazzo, M.; Herren, S.; Gretener, D.; Grahames, C.; Kaur, R.; Kosco-Vilbois, M.H.; Humphrey, P.P. Blockade of human P2 $\times 7$ receptor function with a monoclonal antibody. Blood 1998, 92, 3521-3528.

115. Lin, F.F.; Elliott, R.; Colombero, A.; Gaida, K.; Kelley, L.; Moksa, A.; Ho, S.Y.; Bykova, E.; Wong, M.; Rathanaswami, P.; et al. Generation and characterization of fully human monoclonal antibodies against human Orai1 for autoimmune disease. J. Pharmacol. Exp. Ther. 2013, 345, 225-238. [CrossRef]

116. Cox, J.H.; Hussell, S.; Søndergaard, H.; Roepstorff, K.; Bui, J.V.; Deer, J.R.; Zhang, J.; Li, Z.G.; Lamberth, K.; Kvist, P.H.; et al. Antibody-mediated targeting of the Orai1 calcium channel inhibits T cell function. PLOS ONE 2013, 8, e82944. [CrossRef]

117. Lee, J.H.; Park, C.K.; Chen, G.; Han, Q.; Xie, R.G.; Liu, T.; Ji, R.R.; Lee, S.Y. A monoclonal antibody that targets a Nav1.7 channel voltage sensor for pain and itch relief. Cell 2014, 157, 1393-1404. [CrossRef]

118. Agarwal, J.; Griesinger, F.; Stuhmer, W.; Pardo, L. The potassium channel Ether a go-go is a novel prognostic factor with functional relevance in acute myeloid leukemia. Mol. Cancer 2010, 9, 18. [CrossRef]

119. Gómez-Varela, D.; Zwick-Wallasch, E.; Knötgen, H.; Sánchez, A.; Hettmann, T.; Ossipov, D.; Weseloh, R.; Contreras-Jurado, C.; Rothe, M.; Stühmer, W.; et al. Monoclonal antibody blockade of the human Eag1 potassium channel function exerts antitumor activity. Cancer Res. 2007, 67, 7343-7349. [CrossRef]

120. Fleuren, E.D.G.; Versleijen-Jonkers, Y.M.H.; Heskamp, S.; van Herpen, C.M.L.; Oyen, W.J.G.; van der Graaf, W.T.A.; Boerman, O.C.; Van Herpen, C.M.L.; Van Der Graaf, W.T.A. Theranostic applications of antibodies in oncology. Mol. Oncol. 2014, 8, 799-812. [CrossRef]

121. Guasti, L.; Crociani, O.; Redaelli, E.; Pillozzi, S.; Polvani, S.; Masselli, M.; Mello, T.; Galli, A.; Amedei, A.; Wymore, R.S.; Wanke, E.; Arcangeli, A. Identification of a posttranslational mechanism for the regulation of hERG1 K+ channel expression and hERG1 current density in tumor cells. Mol. Cell Biol. 2008, 28, 5043-5060. [CrossRef]

122. Duranti, C.; Carraresi, L.; Sette, A.; Stefanini, M.; Lottini, T.; Crescioli, S.; Crociani, O.; Iamele, L.; De Jonge, H.; Gherardi, E.; Arcangeli, A. Generation and characterization of novel recombinant anti-hERG1 scFv antibodies for cancer molecular imaging. Oncotarget 2018, 9, 34972-34989. [CrossRef]

123. Duranti, C.; Lottini, T.; Stefanini, M.; Iorio, J.; Petroni, G.; Lastraioli, E.; Arcangeli, A. A novel bispecific antibody to harness the hERG1- $\beta 1$ macromolecular complex for cancer therapy. (Manuscript in preparation).

124. Sanguinetti, M.C. HERG1 channelopathies. Pflugers Arch. 2009, 460, 265-276. [CrossRef] [PubMed]

125. Pillozzi, S.; Masselli, M.; De Lorenzo, E.; Accordi, B.; Cilia, E.; Crociani, O.; Amedei, A.; Veltroni, M.; D’Amico, M.; Basso, G.; et al. Chemotherapy resistance in acute lymphoblastic leukemia requires hERG1 channels and is overcome by hERG1 blockers. Blood 2011, 117, 902-914. [CrossRef]

126. Arcangeli, A.; di Costanzo, F.; Antonuzzo, L.; Messerini, L.; Lastraioli, E.; Iorio, J.; Petroni, G.; Boni, L.; Tofani, L.; Coppola, R.; et al. Predictive power of hERG1 potassium channel expression for response to Bevacizumab in metastatic in colorectal cancer patients. In Proceedings of the EACR AACR SIC 2017, Florence, Italy, 24-27 June 2017.

127. Pointer, K.B.; Clark, P.A.; Eliceiri, K.W.; Salamat, M.S.; Robertson, G.A.; Kuo, J.S. Administration of Non-Torsadogenic human Ether-à-go-go-Related Gene Inhibitors Is Associated with Better Survival for High hERG-Expressing Glioblastoma Patients. Clin. Cancer Res. 2017, 23, 73-80. [CrossRef] [PubMed]

128. Grippo, P.J.; Tuveson, D.A. Deploying mouse models of pancreatic cancer for chemoprevention studies. Cancer Prev. Res. (Phila) 2010, 3, 1382-1387. [CrossRef]

(C) 2019 by the authors. Licensee MDPI, Basel, Switzerland. This article is an open access article distributed under the terms and conditions of the Creative Commons Attribution (CC BY) license (http://creativecommons.org/licenses/by/4.0/). 